UNIVERSIDADE DE SÃO PAULO

ESCOLA DE ENFERMAGEM DE RIBEIRÃO PRETO

Renata Silveira Appolinário

\title{
EDUCAÇÃO PROFISSIONAL: VIVÊNCIA DO EDUCANDO DE ENFERMAGEM NO CUIDADO AO DOENTE CRÍTICO
}

Ribeirão Preto 
Renata Silveira Appolinário

\section{EDUCAÇÃO PROFISSIONAL: VIVÊNCIA DO EDUCANDO DE ENFERMAGEM NO CUIDADO AO DOENTE CRÍTICO}

Dissertação apresentada ao Programa de Pós-Graduação em Enfermagem Fundamental da Escola de Enfermagem de Ribeirão Preto da Universidade de São Paulo, para obtenção do título de Mestre.

Linha de Pesquisa: Educação em Saúde

Orientação: Profa. Dra. Adriana Katia Corrêa

Ribeirão Preto

2007 
AUTORIZO A REPRODUÇÃO E DIVULGAÇÃO TOTAL OU PARCIAL DESTE TRABALHO, POR QUALQUER MEIO CONVENCIONAL OU ELETRÔNICO, PARA FINS DE ESTUDO E PESQUISA, DESDE QUE CITADA A FONTE.

FICHA CATALOGRÁFICA

Appolinário, Renata Silveira

Educação Profissional: vivências do educando no cuidado ao doente crítico. Ribeirão Preto, 2007.

$119 \mathrm{f..;} 30 \mathrm{~cm}$.

Dissertação de Mestrado apresentada à Escola de Enfermagem de Ribeirão Preto/USP - Programa de Pós-graduação em Enfermagem Fundamental.

Orientador: Corrêa, Adriana Katia

1. Educação em Enfermagem. 2. Unidades de Terapia Intensiva. 3. Habilitação Profissional 
Folha de aprovação

Renata Silveira Appolinário

EDUCAÇÃO PROFISSIONAL: VIVÊNCIA DO

EDUCANDO DE ENFERMAGEM NO CUIDADO AO

DOENTE CRÍTICO

Dissertação apresentada ao Programa de Pós-Graduação em Enfermagem Fundamental da Escola de Enfermagem de Ribeirão Preto da Universidade de São Paulo, para obtenção do título de Mestre.

Aprovado em:

Banca Examinadora:

Prof. (a). Dr. (a).

Instituição: Assinatura:

Prof. (a). Dr. (a).

Instituição: Assinatura:

Prof. (a). Dr. (a).

Instituição: Assinatura: 


\section{Dedicatória}

Este trabalho é dedicado especialmente a três pessoas,

A primeira é a que me convenceu nos meus cinco anos de idade, que eu conseguiria passar pelo meu primeiro grande desafio: o de aprender a ler. $\mathcal{E}$ que depois cultivou em mim este gostar. Este trabalho é fruto dessa conquista.

Obrigada mãe

A segunda que me deu força para ir em busca de um sonho, que me deu exemplos e que acima de tudo nunca deixou de me dedicar seu amor e carinho e que mesmo não estando mais fisicamente ao meu lado nunca será esquecido e sempre será fonte de todas as minhas iniciativas. Queria escrever muito mais do primeiro amor da minha vida, mas a única coisa que consigo dizer agora é

Te amo pai

E por último, mas não menos importante minha irmã, Roberta. Que há 12 anos insistiu que eu seria capaz de cursar uma faculdade conceituada, que sempre ficou ao meu lado me incentivando e cuidando de mim como uma mãe. Tive o privilégio de ter você em minha vida e agradeço a Deus todos os dias por isto,

Obrigada Táta 


\section{AGRADECIMESTOS}

Algumas pessoas são especiais, pois fazem parte de nossa vida em todos os momentos, os de alegria, os de tristeza, os de pura irritação e aqueles onde nada de especial está para acontecer, mas, quando estamos sozinhos nos lembramos delas. Graças a Deus essas pessoas são muitas e não caberiam em um pedaço de papel, mas na minha memória todos vocês estão citados.

- minha irmã, Simone e meu cunhado Fernando que acreditaram em mim e depositaram em minha vida grandes esperanças, apesar de todos os desencontros.

- meu cunhado Rafael que me presenteou com meu primeiro computador, que eu tanto usei para escrever esse trabalho.

- Profa. Dra. Adriana Katia Corrêa que mesmo com todos os seus problemas e com a agenda lotada sempre arrumou uns minutinhos para mim, obrigada pelos ensinamentos que levarei não só nesta dissertação, mas em muitos momentos de minha vida. E obrigada por tornar-se não só minha orientadora, mas, meu exemplo.

- Profas. Maria Manuela Rino Mendes, Elizabeth Ranier e Mara Lúcia Garanhani pelas sugestões e carinho nesse meu caminhar.

- Lourdinha e Bernadete pela compreensão e amizade quando sorriam para os meus pedidos no Apoio Bibliográgico Glete de Alcântara.

- Sra. Zilda, Sra. Dedé, Fabiana, Joaãozinho, Edson, todos os profissionais do Centro Interescolar e alunos do II Módulo do Curso de Qualificação em Técnico de Enfermagem do ano de 2006 por terem me acolhido e ajudado nesta trajetória.

- A CAPES pela concessão da 6olsa de mestrado e pelo apoio aos jovens pesquisadores

- A Escola de Enfermagem de Ribeirão Preto - Universidade de São Paulo pela oportunidade de realização do curso de mestrado e pelo apoio aos iniciantes no mundo da pesquisa científica.

- e a todos os meus amigos que vibram comigo por essa conquista. 


\section{Agradecimentos especiais}

A duas pessoas especiais em minha vida, Uma que chegou há dois anos, todos os dias inicia meu dia com um lindo sorriso, mesmo nos meus momentos de cansaço e nervosismo me abraça, me beija e desliga meu computador. Alguém que sempre me faz lembrar que eu posso ser uma pessoa muito melhor, ao grande amor da minha vida, minha filha,

"Assistirei ao desenvolver das tuas idades, guardando todos os teus movimentos. Já está na minha memória a menina mãe de bonecas." (Murilo Mendes, Canto do Soivo, do livro Poesia Completa e Prosa, Ed. Nova Aguilar)

E minha Vida, que está ao meu lado todos os dias, que fica carente quando eu tenho que escrever nos finais de semana e quando o deixo sozinho na cama, nas madrugadas trocando-o pelo computador e pelo meu trabalho. Obrigada por entender minhas ausências, por acreditar em meus sonhos e por sonhar comigo. Às vezes até mais do que eu, me forçando a continuar quando estou doida para desistir, 


\section{RESUMO}

APPOLINÁRIO, RS. Educação Profissional: vivências do educando de enfermagem no cuidado ao doente crítico. Dissertação (mestrado). Escola de Enfermagem de Ribeirão Preto. Universidade de São Paulo. Ribeirão Preto, 2007.

A proposta deste estudo é compreender a experiência vivida pelo educando do curso profissionalizante de enfermagem no aprendizado do cuidado no cenário da terapia intensiva, refletindo sobre essa formação, tendo em vista as perspectivas atuais para a educação de trabalhadores para a saúde e a necessidade de construir o atendimento integral, no contexto do Sistema Único de Saúde (SUS). Fundamenta-se em algumas idéias da abordagem fenomenológica de pesquisa. Foram realizadas observação das experiências no cenário de aprendizagem e entrevistas com onze estudantes de uma Escola Profissionalizante em Enfermagem do município de Ribeirão Preto, SP, que participavam do estágio em terapia intensiva em um hospital público no período de 31 de julho a 11 de outubro de 2006. A entrevista aberta foi conduzida a partir da questão norteadora: "Como tem sido para você cuidar de pacientes críticos nesse momento de sua formação?”. A compreensão da experiência enfatiza o estágio de caráter essencialmente técnico, valorizando a realização de procedimentos mediante a inserção do estudante na rotina do setor, caracterizada pelo modelo biologicista predominante. Apesar disso, em algumas situações, o educando começa a perceber a pessoa internada para além da doença e da técnica, porém, elas são pouco consideradas como integrantes do processo ensinoaprendizagem, bem como a sensibilidade explicitada pelo educando pouco valorizada como dimensão essencial para a construção do compromisso ético-social. Do mesmo modo que o cuidar cotidiano é limitado no sentido de considerar a integralidade da pessoa gravemente doente, o processo ensino aprendizagem não contempla a integralidade do sujeito aprendiz que pensa, sente e age de maneira singular e inserido em um contexto social. Assim, se faz necessário rever o processo formativo, incorporando conhecimentos, habilidades e atitudes voltados à compreensão do cuidado do doente crítico no contexto de saúde atual, do mundo subjetivo e social incluindo familiares e nas questões existenciais como o cerceamento de liberdade e a possibilidade do morrer. Para tal, torna-se fundamental transcender ao treinamento técnico e construir prática educativa, condizente com a formação humanizada para o cuidado de enfermagem

Descritores: educação em enfermagem, unidades de terapia intensiva; habilitação profissional 


\begin{abstract}
APPOLINÁRIO, RS. Professional education: the nursing student's education in the cares for critical patients. Master's Degree dissertation. Ribeirão Preto Nursing School, São Paulo University. Ribeirão Preto, 2007, 118p.
\end{abstract}

This study proposes understanding the student's experience in the nursing professionalizing course in learning the cares for critical patients within the intensive care environment, reflecting over this information, considering the present perspectives for the education of health professionals and the need to build an integral service within the context of the Public Health System (SUS). It is based on a few ideas of the phenomenological approach of the research. The experiences were observed within the learning environment with eleven interviews with students from the Professionalizing Nursing School in the municipality of Ribeirão Preto, SP, who participated in the intensive care internship at a public hospital between July 31 and October 30 2006. The open interview was conducted with the following guidance question: "How has it been for you to take care of critical patients in this moment of your education?". The comprehension of the interviews focuses on the internship as essentially technical, valuing the execution of procedures that enable the student's insertion in the sector routine, which relates to the predominant biologic model. Despite this, in some situations, the student begins perceiving the person staying in the hospital beyond the disease and the technique, nevertheless, these situations are little considered as integrating the teaching-learning process, with the student's initial sensitivity not being valued as an essential dimension for the construction of the ethical-social commitment. In the same manner as the day-to-day care is limited in the sense of considering the integrality of the severely sick person, the teaching-learning process does not contemplate the student integrally as a subject that thinks, feels and acts in a unique manner and that is inserted in a social context. Thus, there is the need to review the education process, incorporating knowledge, abilities and attitudes directed to the understanding of the ICU within the present health context, the subjective and social world of the critical patients and their family members, and the existential issues, such as the restriction of liberty and the possibility of dieing. For such, it becomes fundamental to transcend the technical training and build an educational practice, in agreement with the education of the human being.

Descriptors: nursing education; intensive care units; professional qualification 


\section{RESUMEN}

APPOLINÁRIO, RS. Educación profesional: vivencia del estudiante de enfermería en el cuidado al enfermo en estado crítico. Disertación de maestria - Escuela de Enfermaría de Ribeirão Preto. Universidad de São Paulo. Ribeirão Preto, 2007, 118p.

El objetivo de este estudio es comprender la experiencia vivida por el estudiante del curso de habilitación profesional de enfermería en el aprendizaje para el cuidado de enfermos en estado crítico, en el escenario de los cuidados intensivos, reflexionando sobre esa formación, teniendo en vista las perspectivas actuales para la educación de trabajadores para la salud y la necesidad de construir una atención integral, en el contexto del Sistema Único de la Salud (SUS). Con base en algunas ideas del abordaje fenomenológico de pesquisa se realizó la observación de la práctica en el escenario de aprendizaje y once entrevistas con estudiantes de una Escuela Profesionalizante en Enfermería del municipio de Ribeirão Preto, SP, que participaban de la práctica en cuidados intensivos en un hospital público en el período del 31 de julio al 30 de octubre de 2006. La entrevista, abierta, se condujo con la siguiente cuestión orientadora: “¿Cómo ha sido para usted cuidar a pacientes en estado crítico en este momento de su formación?”. La comprensión de las entrevistas enfoca la práctica como esencialmente técnica, valoriza la realización de procedimientos que posibiliten la inserción del estudiante en la rutina del sector, lo que se relaciona con el modelo biologicista predominante. Sin embargo, en algunas situaciones, el estudiante empieza a percibir a la persona internada más allá de la enfermedad y de la técnica, pero esas situaciones son poco consideradas como integrantes del proceso enseñanza-aprendizaje y la sensibilidad inicial del estudiante nos es valorizada como dimensión esencial para la construcción del compromiso ético-social. Del mismo modo que el cuidar cotidiano es limitado en el sentido de considerar integralmente a la persona gravemente enferma, el proceso enseñanzaaprendizaje no contempla al alumno integralmente, como sujeto que piensa, siente y actúa de manera singular e incluido en un contexto social. Por lo tanto, es necesario rever el proceso formativo, incorporando conocimientos, habilidades y actitudes orientados a la comprensión de la UCI en el contexto de salud actual, del mundo subjetivo y social del enfermo en estado crítico y familiares, y de las cuestiones existenciales como el cercenamiento de la libertad y la posibilidad de morir. Para ello, se vuelve fundamental trascender el entrenamiento técnico y construir una práctica educativa, de acuerdo con la formación del ser humano.

Descriptores: educación en enfermería; unidades de cuidados intensivos; habilitación profesional 


\section{SUMÁRIO}

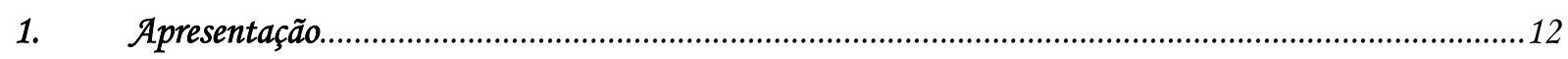

O encontro com a enfermagem: a prática assistencial e a educativa.................................................................13

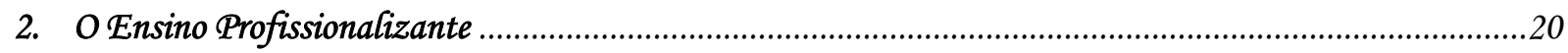

2.1. O ensino profissionalizante no Brasili origens e importância..................................................................21

2.2. A educação profissional em enfermagem no Brasil: consideraçães iniciais ................................................27

3. O Centro de Terapia Intensiva e a Política da Humanização da Atenção à Saúde no Contexto do SUS

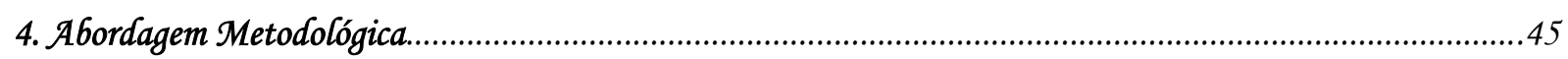

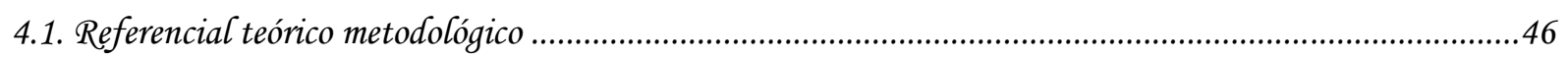

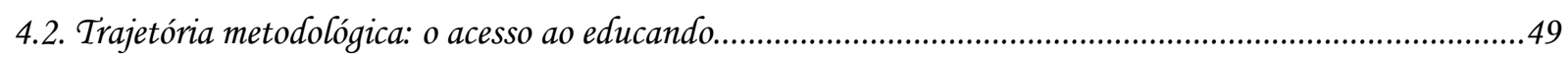

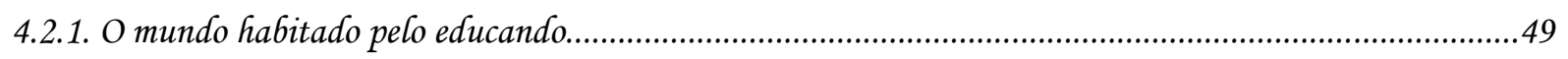

4.2.2. A observação não participante e as entrevistas...................................................................................53

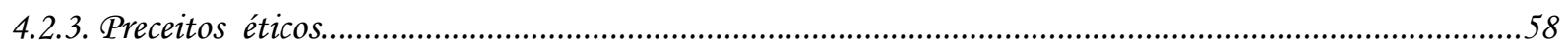

4.2.4. A compreensão do mundo habitado pelo educando..........................................................................59

5. Descrição e Compreensão da Experiência Vivida pelos Educandos ...........................................................61

5.1. Apresentando os alunos pertencentes ao grupo....................................................................................62

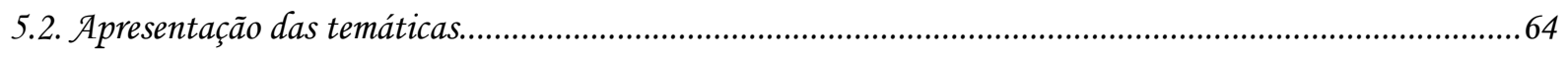

5.2.1. Aproximação do educando ao mundo técnico da terapia intensiva.........................................................65 
Anexos e Apêndice. 116

ANEXO A - Currículo do curso Habilitação Profissional em Técnico de Enfermagem. 117 ANEXO $B$ - Perfil de Competências do Curso de Habilitação Profissional do Técnico de Enfermagem. 118 ANEXO C - Escala de Estágio em 2006. 119 ANEXO D - Aprovação do Comitê de Ética em Pesquisa do HCFMRP/USP 120 APE $\hat{\mathcal{N} D I C E}$ A - Termo de Consentimento Livre e Esclarecido... 
1. APRESENTAÇÃO 
O ENCONTRO COM A ENFERMAGEM: a prática assistencial e a educativa

A escolha do tema para pesquisa pode estar relacionada às experiências vividas ao longo da nossa vida. Assim, antes de explicitar a proposta deste estudo, apresento algumas situações experienciadas que, ao serem retomadas e refletidas, fizeram emergir alguns questionamentos relacionados à formação de trabalhadores para a prática hospitalar junto a doentes em estado crítico, especificamente, trabalhadores de nível médio em enfermagem.

Meu contato com a área hospitalar deu-se muito cedo, com a necessidade de internações freqüentes de meu pai. Mesmo criança ficava impressionada com o cuidado prestado pelos profissionais de saúde que a todo o momento iam verificar algo dentro daquele enorme quarto, com tantos doentes, e também com o carinho demonstrado por eles.

Chegada à hora de escolher minha profissão, as lembranças daquele cenário de carinho e cuidado intensivo que vislumbrei, quando criança, influenciaram-me muito. No cenário hospitalar, a enfermagem tem a oportunidade de estabelecer relações muito próximas com o doente e com os familiares, permanecendo às vezes, por um tempo prolongado ao lado do doente e assim conhecendo melhor seus costumes, sua família e seus problemas cotidianos. Hoje posso dizer que essas características cultivaram em mim a vontade de participar mais ativamente desse ambiente de cuidado, além de, estabelecer contato contínuo com outros setores do hospital, como por exemplo: serviços de radiodiagnóstico, laboratório, serviço de nutrição e dietética e serviços de 
limpeza, realizando assim um papel integrador em uma rede de relações incrivelmente complexa.

Convém também frisar o papel importante do enfermeiro no gerenciamento da unidade hospitalar, administrando constantemente conflitos interpessoais e outros tipos de demandas administrativas. Esse profissional, enfim, neste contexto, deve ter como principal meta a construção do cuidado integral ao doente.

Durante toda a graduação, tive a oportunidade de conhecer várias unidades de internação em um grande hospital universitário, mas impossível negar minha afinidade com o cuidado aos doentes em estado crítico. Impressionava-me o número de procedimentos realizados, além do cuidado prestado à beira do leito, obrigando o profissional a permanecer tão próximo ao doente e ao mesmo tempo distanciado pelo enorme número de equipamentos existentes naquele setor. $\mathrm{O}$ conhecimento dos profissionais que ali permaneciam também me impressionava muito, pois perdurava ainda em mim, assim como em muitas outras pessoas, a idéia de que os intensivistas (profissionais que atuam em cuidados intensivos) eram profissionais mais competentes e mais requisitados dentro das instituições de saúde, além do poder de decisão que era por mim entendido como decidir sobre a vida e a morte dos doentes ali internados.

Assim, ao optar por uma área de trabalho, escolhi o serviço de terapia intensiva por imaginar ser este o cenário mais importante dos serviços hospitalares. Cenário este que hoje reconheço ser importante, principalmente para minha formação, sendo os profissionais, pessoas dotadas de grande competência técnica, entretanto, em determinadas situações específicas, assim como outros profissionais de outros setores, especializações e níveis de atenção em saúde também têm competência para o cuidar. 
Como enfermeira de Centro de Terapia Intensiva em um grande hospital universitário e também enfermeira em uma Unidade de Cuidados Cardiológicos de um hospital-escola de médio porte, por várias vezes me deparei com pessoas iniciantes na área e também com pessoas muito experientes neste setor, e os sentimentos que os envolvia sempre me chamaram a atenção.

O receio do iniciante em se aproximar do doente crítico e o trabalho quase mecânico, normatizado, realizado pelos mais experientes eram situações discrepantes que passavam pelos olhos de todos que ali adentravam, mas pouco era comentado a respeito; é importante salientar que essas situações não eram gerais, e sim marcantes em ocasiões específicas.

Hoje, percebo que o que mais amedrontava os iniciantes e dava extrema segurança aos mais experientes era o lidar com o maquinário específico e o controle biológico do doente instável. Todavia, o doente, o ser humano com vida própria fora do ambiente hospitalar ficava em segundo plano para muitos profissionais, quer iniciantes ou experientes.

Além de exercer minhas atividades profissionais no contexto hospitalar, também atuei na área do ensino, realizando supervisão de estágio de cursos de auxiliares e técnicos de enfermagem. Pude também acompanhar o estágio de alunos dos cursos de graduação em medicina, fisioterapia e enfermagem, atuando como enfermeira assistencial em hospital escola, e exerci atividades de treinamento de trabalhadores de enfermagem que ingressavam nos serviços de terapia intensiva em que trabalhava.

Embora sendo situações diferentes umas das outras, em todas elas observava a insegurança dos iniciantes em realizar procedimentos considerados de baixo risco, em relacionar-se com os familiares e com os pacientes ali internados, sendo que alguns 
tentavam, ao máximo, se distanciar emocionalmente das situações ali ocorridas, enquanto outros até procuravam apoiar o doente e os familiares nas decisões e no cuidado, além da curiosidade em manusear os equipamentos que integravam a unidade de internação.

Entendo o início da atuação profissional em terapia intensiva como um momento peculiar, no qual os ingressantes revelam suas dificuldades e potencialidades para aquele trabalho significativamente centrado em procedimentos e equipamentos altamente especializados, envolvendo ainda o sofrimento de doentes e familiares. E, nesse momento, é possível perceber as lacunas da formação profissional no que se refere às competências técnicas e humanas para esse cuidar.

Entre os profissionais de enfermagem que pude acompanhar quando se inseriam na unidade de terapia intensiva em que eu trabalhava, foram poucos os que, mesmo tendo cursado o técnico em enfermagem, sabiam cuidar do paciente em estado crítico quanto aos aspectos de competência técnica e teórica.

O relacionamento desse profissional com o ambiente ainda novo de trabalho também era por mim considerado agressivo, pois esses novos técnicos de enfermagem eram inseridos no CTI na maioria das vezes prematuramente, sendo para muitos o primeiro contato com esse tipo de situação da prática profissional.

Durante o período que atuei de forma direta na supervisão de estagiários de cursos de auxiliar e técnico de enfermagem, não pude acompanhá-los nos cuidados aos doentes internados na terapia intensiva, já que as escolas a que eu pertencia não obtinham autorização para a entrada de alunos nesse setor, por motivos administrativos. Percebia, porém, em todos a vontade de conhecer o funcionamento desse local de atendimento, envolvendo sua rotina, o manejo dos pacientes e as 
patologias freqüentemente encontradas, ou seja, a intenção era buscar conhecimentos e habilidades de ordem técnico-biológica, obviamente fundamentais para a formação profissional, porém muitas vezes desprovido de sentido humano e social.

Essas vivências provocaram reflexões a respeito da minha ação docente junto aos alunos de curso de auxiliar de enfermagem e do próprio fazer enfermagem no ambiente da terapia intensiva. A partir dessas reflexões, passei a questionar: como o estudante do ensino profissional em enfermagem entende o cuidar de um doente crítico e como ele percebe o doente nesse estado? A forma como se dá o processo de aprendizagem, para prestar esse tipo de cuidado poderá favorecer a construção da integralidade da assistência em saúde? Como o aluno vai apropriando-se ou reapropriando-se do mundo do CTI e como ele se insere nesse contexto?

Os significados que os educandos imprimem à vivência do aprender a cuidar do doente crítico vão se configurando ao longo do seu processo de formação, a partir das experiências e conhecimentos prévios, além dos pensamentos, sentimentos e ações desenvolvidas no cotidiano da terapia intensiva.

Assim, o objetivo deste estudo é compreender a experiência vivida pelo educando do curso profissionalizante de enfermagem durante o aprendizado do cuidado aos doentes em estado crítico, no cenário da terapia intensiva refletindo sobre essa formação tendo em vista as diretrizes atuais para a formação de trabalhadores para a saúde diante da necessidade de construir um atendimento integral, no contexto do Sistema Único de Saúde (SUS).

Este estudo poderá trazer elementos importantes para o processo educativo orientado para o cuidado de enfermagem ao doente crítico, tendo em vista a premência de construir uma prática crítica, ética e humana. 
Cabe mencionar que, apesar dos auxiliares como os técnicos de enfermagem prestarem cuidado em unidades de terapia intensiva, pretendo centrar este estudo na experiência do ensino técnico, considerando que, a ele é dada oportunidade de realizar estágio nesse setor de cuidado, além da aproximação com conteúdo teórico-prático para tal, como parte da sua formação.

Obviamente, eles podem cuidar de doentes considerados "críticos" em outras unidades de internação nas quais realizam o estágio (o que também pode ocorrer com os auxiliares), mas a vivência em um local estrategicamente organizado para tal, facilita a delimitação do projeto pedagógico tendo em vista seu objetivo.

$\mathrm{Na}$ introdução deste trabalho, são abordadas algumas idéias relativas à história do ensino profissionalizante no Brasil, com ênfase à área da enfermagem, bem como algumas considerações sobre o Centro de Terapia Intensiva, no contexto da saúde. Em seguida, realizo uma breve aproximação ao referencial teórico fenomenológico que fundamenta a metodologia do estudo. Tal escolha justifica-se uma vez que o objetivo deste envolve a compreensão das experiências de estudantes de curso técnico de enfermagem, no cuidado ao doente em estado crítico, situação peculiar que envolve a inter-relação de questões subjetivas e existenciais em contexto de saúde (CTI) e de ensino (educação profissional).

Após essa passagem são feitas reflexões a partir das experiências dos sujeitos da pesquisa quando prestando o cuidado em centro de terapia intensiva, como elas se mostraram aos educandos. Em algumas citações é também passado um pouco da sensibilidade do educando quando este vê a necessidade de inter-relacionar-se com o paciente em estado crítico, sem possibilidade de dialogar e como essa situação interfere na assistência a ser prestada. 
Procuro finalizar este estudo realizando uma breve discussão a respeito da compreensão do fenômeno do aprender a cuidar dentro do CTI fundamentada no referencial teórico da fenomenologia. 


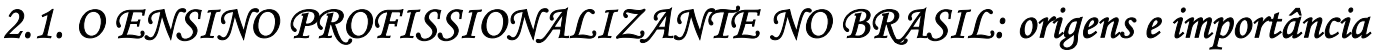

Antes da Revolução Industrial (meados século XVIII) a sociedade era quase que exclusivamente agrícola, sendo que o trabalhador detinha as condições físicas e mentais para controlar o seu processo de trabalho. Era a chamada economia de subsistência, ainda existente em regiões mais afastadas dos grandes centros. $\mathrm{O}$ trabalhador neste modelo econômico é dono e senhor do seu processo de trabalho. Com a introdução do modelo capitalista, o trabalhador passa a ser assalariado, dependente de um empregador e da conquista de bens de consumo mais valorizados (MANFREDI, 2002).

Nesse momento, a classe burguesa passa a ter real importância, em detrimento da força dos reis e da igreja até então dominante. A educação burguesa assume a tarefa de aprimorar a livre força de trabalho humano, transformando-a em mercadoria. Há neste modelo a procura pelo aumento da produção e, assim, do lucro do senhor industrial resultando no aumento do número de pobres e miseráveis nas cidades gerando a necessidade de criação de políticas educacionais e econômicas. Ambiente em que se formaram os sindicatos e os ideais societários (FRIGOTTO, 2002).

A visão capitalista do ensino, presente após a Revolução Industrial, visa à superioridade do "poder saber" sobre o "poder fazer" humanos, ainda presente nos dias atuais: a uma pequena parcela da população é priorizado o ensino clássico, teórico,

literário, já que a essas pessoas são destinadas funções de dirigentes, enquanto à grande maioria é priorizado o ensino prático, a fim de formar mão de obra para o 
mercado de trabalho. Sob esta dicotomia entre o "saber fazer" e o "saber pensar" é que a maior parte dos indivíduos é formada desde os tempos mais remotos (LOBO NETO et al, 2000).

A concepção burguesa de trabalho trouxe a interpretação de que o processo do trabalho é reduzido a produto, objeto, mercadoria que aparece como trabalho abstrato em geral, sendo que a força de trabalho perde assim a concepção inicial de que trabalho é relação social e que na sociedade capitalista constitui-se numa relação de força, poder e violência. De outro lado, está a teoria de que "o trabalho é a relação social fundamental que define o modo humano de existência, e que, enquanto tal, não se reduz à atividade de produção material para responder à reprodução físico-biológica, mas envolve as dimensões sociais, éticas, estéticas e culturais" (FRIGOTTO, 2002).

No Brasil, o Liceu de Artes e Ofícios, fundado em 1858, no Rio de Janeiro, pode ser considerado um dos marcos da educação profissional. Seguindo o exemplo de escolas estrangeiras, principalmente as européias, destinadas a ensinar mais artes que ofícios, pois a construção de laboratórios ainda não era considerada importante para os educadores da época, sendo privilegiado o ensino na prática profissional propriamente dita (BARATO, 2002).

Os primeiros investimentos neste campo da educação são da década de 1940, quando o governo brasileiro passa a definir medidas e ações a fim de capacitar e formar profissionais para a indústria nacional, visando o crescimento econômico que tomava impulso diante das necessidades criadas pelo advento da Segunda Guerra Mundial. Em 1942, é criado o Serviço Nacional de Aprendizagem dos Industriários (SENAI) e instituída a Lei Orgânica do Ensino Industrial. Em 1943, é promulgada a Lei Orgânica do Ensino Comercial e, em 1946, é criado o Serviço Nacional de 
Aprendizagem Comercial (SENAC) e outorgada a Lei Orgânica do Ensino Agrícola (LOBO NETO et al, 2000).

A educação para o trabalho sofreu várias modificações a fim de se adequar ao modelo econômico vigente, passando pelo conhecimento mestre-aprendiz à concepção de uma educação política e criativa focalizando o ensino de competências, preparando o aprendiz para o mercado de trabalho e para as relações sociais ali existentes.

As transformações na área econômica do Brasil, principalmente nos últimos trinta anos, obrigaram o governo federal a participar mais ativamente no direcionamento da formação técnica dos cidadãos, para que pudessem acompanhar a revolução tecnológica em curso.

O crescimento das escolas profissionalizantes, fruto do sistema capitalista, com caráter prático - formal, faz parte de um movimento que busca homogeneizar, massificar e especializar o trabalho e, assim, cria estratificações internas nos distintos grupos sociais (MANFREDI, 2002).

Nascem, assim, vários projetos e políticas educacionais de nível básico, no contexto nacional acompanhando o movimento internacional. Entre eles, destaca-se o Plano Nacional de Formação (Planfor), estruturado em 1995, como proposta de dinamização dos programas financiados pelo Fundo de Assistência ao Trabalhador (FAT) tendo como linhas direcionadoras o desenvolvimento de estratégias destinadas à qualificação e capacitação de trabalhadores e à sua formação contínua, distanciandose do conceito de treinamento difundido pelas empresas na época (MANFREDI, 2002).

A educação, como intervenção nas relações sociais, tem grande espaço a ser descoberto no mundo do trabalho, e isso significa submeter a escola a uma avaliação 
transformadora no sentido de buscar a quebra da histórica divisão entre o trabalho intelectual e o trabalho manual (GÓMEZ, 2002).

Essa perspectiva discutida no meio acadêmico, político e nas camadas populares há várias décadas, foi intensificada na década de 1990, quando da reformulação da Lei de Diretrizes e Bases (LDB) da Educação Nacional, momento no qual a Comissão de Educação e Cultura optou por promover novas discussões com educadores de todo território nacional (BRASIL, 2000a).

Os cursos técnicos são freqüentemente acusados de serem pouco eficazes, demasiadamente longos e extremamente teóricos não preparando adequadamente os educandos que a eles procuram, conseqüentemente dificultando a atuação desses nas profissões de nível médio em que se formam. Contrapondo-se a isto a nova LDB indica a realização do curso técnico em módulos, que fornecem qualificações parciais e podem ser cursados em diferentes escolas e em tempos diferentes (BRASIL, 2000b).

Pelo artigo $n^{\circ} .39$ da nova LDB é assegurado ao aluno egresso do ensino fundamental, médio e do ensino superior, bem como ao trabalhador, a possibilidade de acesso à educação profissional, que se propõe a favorecer o permanente desenvolvimento de aptidões para a vida produtiva (MENDES, 2003).

A nova LDB reconhece a abrangência da educação e estabelece que a educação escolar deva vincular-se ao mundo do trabalho e à prática social (Lei nº. 9394/96, Art. $1^{\circ}$ ), o desafio que se apresenta é integrar a escola e a prática profissional, criando um sistema flexível e permanente de educação para o trabalho (BRASIL, 1996a). 
A necessidade de definição de um perfil de qualificação profissional que permita ao técnico construir seus próprios itinerários profissionais seria inviabilizada se essa formação estivesse atrelada ao ensino médio. Assim, o decreto $n^{\circ}$. 2.208/97, em seu artigo $3^{\circ}$, estabelece os três níveis de formação do ensino profissionalizante, sendo eles: o ensino de nível básico fazendo referência aos cursos de curta duração, para qualificação, requalificação e reprofissionalização dos trabalhadores em geral; o ensino de nível técnico, destinado àqueles que estejam cursando ou tenham concluído o ensino médio, conferindo ao educando o título de técnico ou auxiliar e; o tecnológico, compreendendo cursos de nível técnico superior, cursos de curta duração, geralmente de dois anos, destinado aos egressos do nível técnico e ensino médio, porém, não concedem ao egresso o título de graduado (SANTOS, 2005; BRASIL, 2007).

Entretanto, essas mudanças trouxeram a idéia de que o ensino superior, tão almejado por diversos segmentos da população, ficasse ainda mais distante da parcela que dispõe de escassos recursos financeiros visto que tendo o acesso ao ensino técnico já possuirão uma profissão. Esta proposta ganhou vários adeptos que defendiam a hipótese de que essas mudanças no ensino profissional serviriam, somente, para conter o aumento do número de vagas do ensino superior (MENDES, 2003).

Segundo esta mesma autora, o número de egressos do ensino médio vem aumentando nos últimos anos, enquanto o aumento do número de vagas nas universidades é pouco expressivo, sendo então os cursos pós-ensino médio, de curta 
duração, uma alternativa na formação para o acesso ao mercado de trabalho para muitos.

Em estudo realizado pelo Conselho Nacional de Educação e citado por Mendes (2003), no qual buscou caracterizar os egressos de cursos pós-médio do Rio de Janeiro durante 1999 e 2000, verificou-se que 74\% destes haviam realizado exames vestibulares, mas apenas 59\% obtiveram aprovação, sendo que, 55.6\% obtiveram aprovação para as instituições públicas de ensino superior. Dentre estes, $43.7 \%$ eram egressos de escola particular, $42.4 \%$ de escola pública e $13.8 \%$ haviam cursado parte em escola pública e a outra em escola privada. E, também a maior parte dos egressos de escolas públicas não havia conseguido entrar em instituições públicas de ensino superior. Diante do exposto, o ensino técnico é a única opção de conseguir a profissionalização. Nesta pesquisa, também se conclui que $98.1 \%$ pretendiam realizar um curso superior na mesma área em que cursavam o ensino de nível técnico. Para eles, o curso superior permitiria a aquisição de conhecimentos mais profundos e traria maior possibilidade de ascensão profissional e social.

Aproximadamente dez anos da promulgação da nova LDB e do decreto $\mathrm{n}^{\circ}$. 2.208/97, que proibia a realização do ensino médio integrado à educação profissional técnica houve sua revogação pelo Decreto $n^{\circ}$. 5.154/2004. Essa iniciativa do atual governo veio atender à expectativa de muitos militantes do campo da educação que denunciavam os efeitos da separação entre formação geral e técnica como uma das bases da divisão estrutural da sociedade entre a elite educada destinada a pensar e conduzir os demais a serem treinados para trabalhar e obedecer. Esse decreto diz que os cursos de formação inicial e continuada devem, preferencialmente, ser articulados com a Educação de Jovens e Adultos (EJA) (BRASIL, 2004; BRASIL, 2007).

Segundo Gaudêncio Frigotto, na I Conferência Nacional de Educação Profissional e Tecnológica, que ocorreu no final de 2006 , a população brasileira foi criada a partir da cultura do "caminho mais curto", por isso o alto índice de procura pelo ensino 
profissionalizante, e a maior taxa de ocupação das vagas nessas escolas mais conceituadas por jovens de classe média e não por camadas sociais mais baixas (BRASIL, 2007).

Após este breve relato da educação profissional no Brasil, sua história e implicações na sociedade, faz-se importante realizar uma aproximação com a educação profissional em enfermagem no contexto nacional.

2.2. A EDUCAÇÃO PROFISSIONAL EM ENFERMAGEM SO BRASIL: considerações iniciais

O censo escolar, realizado pelo Instituto Nacional de Estudos e Pesquisas (INEP), de 2006 aponta que a área da saúde é a que tem maior número de alunos matriculados na educação profissional no país, responsável por 31.5\% das matrículas, seguida pela Gestão, Indústria e Informática (BRASIL, 2007).

De acordo com a publicação anterior, a pesquisa mostra a expansão de $26.9 \%$ da Educação Profissional no Brasil entre 2003 e 2005. Nesse período, o número de escolas que oferecem cursos dessa modalidade educacional subiu de 2.789 para 3.294, revelando um aumento de 18.1\%. Entre esses 505 novos estabelecimentos, podem ser contabilizadas as Escolas Técnicas do Sistema Único de Saúde (ETSUS) que nasceram nesse período, principalmente na região norte do país. A quantidade de estudantes cresceu em proporção ainda maior que as escolas, passando de 583.5 mil 
para 747 mil, um salto de $26.9 \%$. Na área da Saúde, esse número aumentou cerca de 36\% desde 2003. Outro dado é a grande participação dos estabelecimentos privados nessa oferta de cursos técnicos, mais de $70 \%$ nos três anos, contra $19.9 \%$ das instituições estaduais, $4.7 \%$ das federais e $4.2 \%$ das municipais (BRASIL, 2007).

O relatório apresenta ainda a distribuição desses estudantes segundo sexo e faixa etária. Na saúde as mulheres são maioria na procura pelos cursos de educação profissional totalizando cerca de $70 \%$. Desses, $73 \%$ têm entre 20 e 39 anos, o que dada à numerosidade de matrículas em Saúde, explica o crescimento das faixas de idade mais velhas no resultado geral. Mas esses dados, especificamente, não contemplam aqueles que estudam na modalidade integrada — em que o ensino médio e a educação profissional compõem um único currículo e matrícula.

Levando-se em conta esses dados tão expressivos a respeito do crescimento da educação profissional em saúde, e em especial, na enfermagem, considero relevante explicitar como vem se dando o desenvolvimento da profissão no decorrer da história, julgando cabível esse conhecimento para futuros docentes da área, mostrando a importância do técnico e auxiliar de enfermagem no contexto da saúde brasileira.

São de fundamental entendimento os aspectos político-legais relacionados à educação profissional em enfermagem, não somente para viabilizar e organizar a sua oferta, mas principalmente para que os enfermeiros docentes envolvidos possam refletir sobre ela no contexto brasileiro, além de contribuir para a construção da formação crítico-reflexiva.

Historicamente a enfermagem no Brasil acompanha a evolução do ensino médico, o primeiro decreto regulamentando a função de parteiras, vinculado ao curso de medicina, data de 1832, sendo o exercício profissional regulamentado através do 
Decreto $\mathrm{n}^{\circ}$. 828 de 29.09.1851 da Junta de Higiene Pública, em que médicos, cirurgiões, boticários, dentistas e parteiras deveriam apresentar seus diplomas à Corte e Província do Rio de Janeiro (OGUISSO; SCHIMIDT, 1999).

No ensino de enfermagem, registra-se a primeira escola de formação de enfermeiros "Escola de Enfermeiras Alfredo Pinto", fundada em 1890, na cidade do Rio de Janeiro e dirigida, exclusivamente, por médicos, visando à formação de pessoal para trabalhar na área de psiquiatria. Em 1923, é inaugurada a Escola Anna Nery também na cidade do Rio de Janeiro, firmada padrão para a formação de enfermeiros pelo Ministério da Saúde. Nesta década, foi instituído o Departamento Nacional de Saúde Pública, e em 1930, o Ministério da Saúde e da Educação assumem o comando dessas áreas, definindo normas e leis cabíveis a elas (CAPELLA; FARIA; GELBCKE; SPRICIGO, 1988; BARTMANN, 2004).

Seguindo os passos da enfermagem nightingaleana (Inglaterra), o Brasil adotou a distinção entre o saber fazer e o pensar, por meio da divisão de categorias no contexto da profissão. As enfermeiras formadas pelas escolas da época detinham o saber, enquanto mulheres sem instrução acadêmica e, apenas, contando com a boa vontade na realização dos cuidados, eram responsáveis pelo fazer prático.

Com a necessidade de um maior número de profissionais com treinamento específico para os serviços de enfermagem, ocorre à expansão de escolas formadoras de nível técnico (básico). A primeira escola de auxiliar de enfermagem, em 1936, a Escola Carlos Chagas em Belo Horizonte, manteve a segmentação do trabalho da enfermagem, na qual os enfermeiros eram formados para a administração e supervisão, enquanto os auxiliares para a execução de tarefas de cuidado (CAPELLA; FARIA; GELBCKE; SPRICIGO, 1988). 
A Lei $\mathrm{n}^{\circ} .775$ de 06.08.1949 dispõe sobre o ensino de enfermagem no país, incluindo um preceito referente ao artigo $n^{\circ}$. 21, dispondo que "as instituições hospitalares, públicas ou privadas, decorridos sete anos após a publicação desta lei, não poderiam contratar, para a direção de seus serviços de enfermagem, senão enfermeiros diplomados". Somente na década de 1950 é que o governo regulamenta uma lei na qual são definidas as categorias de enfermagem no país, sendo elas: os enfermeiros diplomados, enfermeiros práticos, auxiliares de enfermagem, atendentes de enfermagem e parteiras, tratando efetivamente do exercício profissional de enfermagem (OGUISSO; SCHMIDT, 1999).

Com a Lei $n^{\circ} .3 .780$ de 12 de julho de 1960, o enfermeiro passa a ser reconhecido como categoria de nível universitário, recebendo assim a remuneração correspondente e em 1961, é regulamentado o exercício da enfermagem, havendo aqui uma tentativa de definição do exercício profissional, ainda restrito à observação e ao cuidado do doente, gestante e acidentado, administração de medicamentos e tratamentos prescritos pelo médico, educação sanitária e aplicação de medidas de prevenção de doenças. Este decreto definiu também todas as categorias que poderiam exercer legalmente a profissão inclusive as obstetrizes e parteiras, havendo ainda a indefinição de funções de enfermagem entre todas as categorias existentes (OGUISSO; SCHMIDT, 1999).

Os atuais dispositivos legais do exercício profissional de enfermagem foram regulamentados pela Lei $n^{\circ} .7 .498$ de 25 de junho de 1986 e pelo Decreto $n^{\circ} .94 .406$ de 08 de junho de 1987, estabelecendo as competências privativas dos enfermeiros inexistentes na lei anterior, sendo também atribuídas às funções dos técnicos de 
enfermagem, já que mesmo existindo o curso desde 1961, o seu exercício profissional não era até então regulamentado (COREN/SP, 2001).

Os cursos técnicos passaram a existir após a promulgação da Lei de Diretrizes e Bases (LDB) de 1961, sendo o primeiro curso técnico em enfermagem organizado em 1966, pela Escola Anna Nery. No entanto, esse profissional só passou a existir legalmente a partir de 1976 por meio da circular do Conselho Regional de Enfermagem, São Paulo (COREN/SP), n. 2/76 (OGUISSO; SCHMIDT, 1999).

A criação do curso técnico já era cogitada pela Associação Brasileira de Enfermagem (ABEN) há vários anos, mas não contava com a aprovação de muitos enfermeiros que viam neste novo profissional uma ameaça à sua categoria. Mas, devido ao despreparo dos auxiliares de enfermagem no atendimento aos doentes em estado crítico e ao reduzido número de enfermeiros, é que em 1965, a ABEN solicita a criação deste curso ao Conselho Federal de Educação (CFE) (SANTOS, 2005).

Em 1977, instituiu-se a Habilitação Profissional do Técnico em Enfermagem com base na Resolução CFE $n^{\circ}$. 7/77 tendo como objetivos a formação de profissionais capazes de planejar e prestar cuidados integrais de enfermagem ao indivíduo na saúde e na doença, participar da equipe de saúde e chefiar unidades de enfermagem que não fossem centros de ensino, sob supervisão do enfermeiro (KOBAYASHI, 2002; BARTMANN, 2004).

Seguindo a Escola de Administração Científica, oriunda da Teoria de Taylor, a enfermagem brasileira foi submetida à divisão do trabalho, descrição de cargos e tarefas e a um controle realizado pela pessoa que recebe a designação de supervisor. A preocupação primordial da enfermagem, nesse sentido, reside em organizar e 
executar uma tarefa; para isto surgem as tarefas fracionadas, a especialização e a padronização do trabalho (PIRES; GELBECKE; MATOS, 2004).

A tendência à especialização do trabalho está relacionada à incorporação de tecnologia na saúde, o que amplia os tipos e quantidades de trabalhadores para operações cada vez mais especializadas, o que se coaduna com a organização funcionalista do trabalho e o modelo clínico de atenção (LIMA, 1998).

Cabe ressaltar que a enfermagem brasileira vem organizando o seu processo de trabalho na modalidade funcional, com a finalidade de economia de tempo e de maior habilidade durante a execução do serviço; apresentando uma prática fragmentada, que não contempla a integralidade da assistência, diferenciando cada vez mais o trabalho técnico do trabalho intelectualizado, no contexto do modo de produção capitalista (SANTOS, 2005).

O incentivo à organização de serviços de saúde e a modernização dos hospitais passou a enfatizar a assistência individualizada e atuação dos enfermeiros na administração, supervisão e ensino de pessoal de enfermagem enquanto os auxiliares e técnicos de enfermagem permanecem no atendimento direto e individualizado ao doente, seguindo as práticas do modelo clínico vigente, privilegiando o atendimento cada vez mais especializado e fragmentado.

Entretanto, durante a década de 1980, o denominado movimento da reforma sanitária adquiriu impulso e dimensão nacional, explicitando a percepção da saúde não como contraposição à doença, mas como resultante de uma totalidade da qual é integrante e na qual interferem múltiplas dimensões, incluindo as esferas biológica, histórica e social, simultaneamente (AMÂNCIO FILHO, 2004). 
O Sistema Único de Saúde (SUS) representa a concretização do longo processo de discussão da política nacional de saúde, um novo modelo assistencial para a organização de suas ações, tendo como princípios direcionadores: universalidade e eqüidade, descentralização, regionalização e hierarquização da assistência, atendimento integral à saúde, participação da comunidade e, recentemente incluída, humanização da assistência, que dentre outros destaca o acolhimento, vínculo e responsabilização em uma perspectiva do atendimento integral do ser humano (EBISUI, 2004).

Entretanto, o SUS tem sido caracterizado por avanços e retrocessos determinados tanto pela dimensão geográfica e heterogeneidade do país, como por interesses políticos e ideológicos que norteiam os rumos da economia e da saúde no Brasil (EBISUI, 2004).

Ao mesmo tempo em que eram discutidas suas diretrizes foram iniciados debates a respeito dos profissionais de saúde que exerceriam funções neste modelo de assistência; o trabalho dos atendentes de enfermagem, que executavam tarefas de enfermagem sem formação específica, passa a ser excluído, em acordo com a Lei nº. $7.498 / 86$, em seu artigo $n^{\circ} .23$, que estabelecia um prazo de dez anos, a contar da promulgação da mesma, para que estes trabalhadores pudessem continuar a exercer suas atividades, devidamente autorizados pelo Conselho Federal de Enfermagem (COFEN), após a adequada qualificação, seja através de provas ou cursos, de modo a ascenderem com o auxiliar de enfermagem (BRASIL, 1986).

Ao longo do tempo, face à complexidade do processo de extinção da categoria atendente, considerando questões de ordem política e econômica, não sendo simples realizar um investimento formativo para um elevado número de trabalhadores nesse 
período de tempo, foi criada a Lei $n^{\circ}$. 8.967/94 que não institui prazo legal para formação específica, mas proíbe que atendentes realizem o cuidado direto em instituições públicas ou privadas à população (BRASIL, 1994).

Torna-se impossível, com o SUS, pensar nos recursos humanos pertencentes ao sistema sem considerar a natureza e as finalidades da atividade que estes desenvolvem. Para grande parte dos trabalhadores de enfermagem, auxiliares e atendentes, faltava qualificação técnica mínima para o exercício da própria profissão.

A formação de recursos humanos é reconhecida pelo Ministério da Saúde como ponto fundamental para a execução dos princípios e diretrizes do SUS, entretanto, a maioria dos profissionais não tinha acesso a um processo formal de ensino apenas a treinamentos e capacitações, que poderiam significar ganhos na atuação do profissional, mas que não correspondiam a sua formação mínima.

Tais trabalhadores não qualificados são capazes de atender às necessidades concretas do serviço, à medida que essas Ihes chegam traduzidas na forma de tarefas específicas a serem realizadas, assim se tornam cumpridores de ordens de trabalho, tornando-se facilmente descartados, por não serem detentores de conhecimento (BRASIL, 2000b: 63).

Nesse contexto, surgem nas décadas de 1980 e 1990 projetos educacionais que visavam o preparo e qualificação dos profissionais de saúde para o atendimento adequado aos usuários do novo sistema de saúde. Entre eles destaca-se o Projeto Larga Escala como nova estratégia de formação de recursos humanos para o setor saúde, com o objetivo de qualificar profissionais de nível médio e elementar, que atuavam nos serviços públicos de saúde (GRYSCHEK; ALMEIDA; ANTUNES; MIYASHIRO, 2000). 
Entre as principais características do Projeto Larga Escala podem ser destacadas: análise das práticas assistenciais arriscadas a que os usuários do sistema de saúde eram submetidos; análise de práticas educacionais tradicionais e conservadoras voltadas para a qualificação desses profissionais, rompendo com as práticas utilitaristas da época; reconhecimento da distância entre as propostas de formação e a realidade concreta vivida por esses profissionais, com ênfase tecnicista, mecânica e descontextualizada; uso de metodologia de integração ensino-serviço e criação de mecanismos de promoção profissional e educativa do profissional auxiliar em saúde, inclusive pela compreensão da necessidade de ampliar sua formação escolar geral (BRASIL, 2000a: 61).

A formação de recursos humanos em saúde voltada para a consolidação do SUS, implica na responsabilidade de fornecer subsídios teóricos e práticos para que o profissional possa atender o ser humano em suas necessidades de saúde. 0 trabalhador deve ser considerado mais do que mão-de-obra, insumo no sistema de produção, mas, de modo mais abrangente, como sujeitos desse processo, agentes sociais de mudança (GÓES, 1999).

Preocupado com a qualificação desses trabalhadores e com a melhoria da atenção à saúde, minimizando os riscos e agravos à população, o Ministério da Saúde lança, em 1999, um novo Projeto de Profissionalização dos Trabalhadores da Área de Enfermagem, o PROFAE, que busca além da profissionalização dos atendentes de enfermagem, o aprimoramento de auxiliares, a formação do técnico de enfermagem e, também, o preparo de enfermeiros para a docência na educação profissional (BRASIL, 2001). 
É importante ressaltar que essa profissionalização exige o acesso ao ensino fundamental e, mesmo, com o grande número de núcleos formadores de profissionais de enfermagem, principalmente no estado de São Paulo, são poucas as instituições que têm a possibilidade de executar a política educacional vigente e responder às demandas sociais (OLIVEIRA; LAMPE; MARTINS; MIYASHIRO, 2002).

O PROFAE buscou para qualificação desses recursos humanos em enfermagem, convênios com escolas experientes na formação desta categoria profissional, fornecendo aos educandos, aproximadamente 225.000 , o certificado de qualificação técnica de auxiliar de enfermagem e 90.000, auxiliares de enfermagem qualificados como técnicos; além de promover a escolarização de 95.000 trabalhadores que não haviam concluído o ensino fundamental. Ainda possibilitou a formação de aproximadamente 12 mil enfermeiros-docentes, por meio da educação à distância, na modalidade semi-presencial, articulando teoria e prática ao longo do seu desenvolvimento. Pretendia-se com isto melhorar a qualidade da atenção e da educação profissional em enfermagem, já que, esses novos educadores mudariam a forma de lidar com as equipes e até mesmo possuiriam melhor articulação com seus educandos de nível médio (BRASIL, 2001a).

Além do exposto, soma-se a Resolução do Conselho Federal de Enfermagem (COFEN) nº. 276/2003 (BRASIL, 2003) que regula a concessão da inscrição provisória ao Auxiliar de Enfermagem, tendo este um prazo de cinco anos para a efetivação da qualificação de técnico, tornando-se urgente a efetiva consolidação do nível técnico de ensino profissionalizante em enfermagem, o que demanda a formação do profissional docente nesta área. 
Segundo as Diretrizes Curriculares Nacionais para a Educação Profissional de Nível Técnico (BRASIL, 1999a), Parecer nº 16/99, entende-se por competência profissional a capacidade de articular, mobilizar e colocar em ação valores, conhecimentos e habilidades necessários para o desempenho eficiente e eficaz de atividades requeridas pela natureza do trabalho. Os valores se expressam no saber ser, na atitude relacionada com o julgamento da pertinência da ação, a qualidade do trabalho, a ética do comportamento, a convivência participativa e solidária e outros atributos humanos, tais como a criatividade e a iniciativa (EBISUI, 2004).

Compreendo que esta articulação e mobilização de conhecimentos, habilidades e valores são fundamentais, e, em se tratando do foco deste estudo a apropriação do cuidar em terapia intensiva pelo estudante de nível técnico, tal articulação poderá criar condições para a construção do cuidado integral. Não apenas centrado na técnica e na dimensão biológica, mas no cuidado da pessoa gravemente enferma, considerando-a como ser social e subjetivo. 
3. O CENTRO DE TERAPIA INTENSIVA E A POLÍTICA DE HUMA ANIZAÇÃO DA ATENÇÃO À SAÚDE NO CONTEXTO DOSUS 
Para melhor entender como se dá a inserção do educando do curso Habilitação Profissional em Técnico de Enfermagem no mundo do Centro de Terapia Intensiva (CTI) é importante apresentar algumas características acerca deste local específico de atendimento hospitalar.

Partindo da definição adotada por Vila (2001), o Centro de Terapia Intensiva é o local onde são internados doentes "potencialmente graves e recuperáveis", em sistema de vigilância contínua, sendo esta necessária em vista de mudanças rápidas nos parâmetros clínicos, o que exige decisões imediatas e de baixa tolerância a erros diagnósticos e terapêuticos.

Como unidades hospitalares providas de tecnologia e com características próprias para o atendimento de pacientes críticos, o CTI não se encontra dissociado do contexto institucional, fazendo parte de um macro sistema sujeito às mudanças vinculadas à administração adotada pela instituição e pelos demais serviços de saúde.

Um paciente de terapia intensiva deve ser visto de forma diferente de um paciente de enfermaria, pois muitos aspectos os diferenciam como: a gravidade e a agudeza de sua condição clínica, os aspectos legais, deontológicos e bioéticos, o relacionamento interpessoal dos múltiplos segmentos envolvidos na atenção ao paciente, a interface com o equipamento e o próprio ambiente físico (PINHEIRO, 2001).

Considerado um sistema complexo dotado de "status", poder, papéis e metas, além de programas, processos e recursos próprios, deve considerar as diferenças individuais de cada paciente, devendo ser ajustadas na medida da prestação do cuidado (SILVA, 1998).

Historicamente, as primeiras tentativas de observação contínua dos pacientes surgiram na década de 1930, com as salas de recuperação pós-anestésica. Os CTIs 
surgem na década de 1950 como um "sistema tecnológico de instrumentos, conhecimentos e habilidades" destinados à assistência do indivíduo criticamente enfermo (PEIXOTO, 1996; VILA, 2001).

No Brasil, o surgimento do Centro de Terapia Intensiva coincide com o período do chamado "milagre econômico", década de 1970, no qual a política se caracterizava, essencialmente, pela busca de modernização, com a finalidade de prestar uma assistência vinculada à tecnologia de ponta. Assim, ocorria a absorção de avanços tecnológicos, recursos farmacêuticos e de equipamentos, bem como o desenvolvimento de métodos diagnósticos e terapêuticos (CORRÊA, 1995; VILA, 2001; URIZZI, 2005).

Mesmo com a melhora do atendimento no nível básico proposta pelas atuais políticas públicas de saúde, importante para a qualidade de vida da população, a terapia intensiva continuará recebendo pacientes que realmente necessitem em maior densidade de tecnologia em decorrência, por exemplo, de trauma e doenças crônicodegenerativas, devendo, portanto estar preparada para o tipo de atendimento exigido pela população. Assim, convém considerar a terapia intensiva como um espaço de atendimento terciário que precisa se articular aos demais níveis de atenção, constituindo uma rede de cuidados cujos princípios da integralidade, equidade, acessibilidade, dentre outros, sejam assegurados às pessoas que realmente necessitarem de cuidados intensivos. (URIZZI, 2005).

Recentemente, a fim de melhor adequar as instituições públicas de saúde às diretrizes básicas do SUS, o Ministério da Saúde instituiu o programa de humanização da assistência (Humaniza SUS), no qual, além da preservação da autonomia e direito à informação sobre a saúde das pessoas assistidas, incentiva mudanças na formação dos profissionais responsáveis pela execução do cuidado. 
O Programa Nacional de Humanização da Assistência Hospitalar (PNHAH) tem como principal objetivo aprimorar as relações entre profissionais de saúde e usuário, dos profissionais de saúde entre si e do hospital com a comunidade. Propõe para isso ações de valorização da dimensão humana e subjetiva presente em todo ato da assistência à saúde, transformando as instituições públicas de saúde em organizações mais modernas, dinâmicas e solidárias em condições de atender às expectativas dos gestores e da comunidade (BRASIL, 2001b).

Na prática a política de humanização do Ministério da Saúde, passou a englobar ações para organização da porta de entrada, reformulação arquitetônica para tornar o ambiente acolhedor e utilização de práticas alternativas de educação em saúde. O centro das preocupações da saúde passa a ser sujeito além da crítica à tecnologia da assistência (BRASIL, 2006).

De acordo com Corrêa (2000), é necessário considerar o aspecto humano nos serviços de terapia intensiva, mesmo que em meio às aparelhagens e técnicas complexas, em que o sujeito vivencia o processo patológico, que envolve a sua totalidade existencial, sem dúvida o faz experienciar a insegurança diante da doença e o risco de morte.

Assim, o que precisa ser posto em questão é o quanto a dignidade humana vem sendo ou não considerada quando o homem está gravemente doente e o respeito aos seus direitos.

Isso revela a necessidade premente de investimento na humanização do trabalho em terapia intensiva, o que representa um grande desafio face às particularidades desta prática que torna o fazer mecanicista a única maneira de produzir cuidados, fazer este centrado predominantemente aos aspectos biológicos. 
O investimento em humanização do cuidado também precisa ocorrer nos modos como se processa a formação profissional nesse contexto visto que, elas reproduzem o trabalho tecnicista cotidiano. Logo, torna-se necessário questioná-lo, ressignificá-lo, construir modos de cuidar acolhedores, éticos e tecnicamente efetivos voltados à pessoa humana.

A humanização da assistência em saúde proposta pelo PNHAH é uma proposta de mudança do modelo e da cultura e isso só se faz com formação.

Segundo os modelos conhecidos de avaliação o aluno pode ser reprovado ou interrompido em sua trajetória se não comprovar competência técnica ou habilidades, mas não existem instrumentos que o impeçam de seguir sua formação se ele não for capaz de escutar, conversar, ter flexibilidade, ou seja, não suprir os requisitos para o atendimento acolhedor, com vínculo e integral (BRASIL, 2006).

É conhecida a preocupação do aluno, ao adentrar no CTI, em conhecer todo o aparato tecnológico com que ele se defronta, mas, ao vivenciar esse ambiente, ele percebe que não só o maquinário merece destaque, mas também as relações interpessoais, ainda desconhecidas, ganham especial atenção (VILA, 2001).

Todavia, ao voltar-se para outras questões, além do aparato tecnológico, estará o aluno encontrando condições de refletir sobre a prática do cuidado em $\mathrm{CTI}$, atuando como agente transformador da forma de atender o doente?

A complexa rotina diária que envolve o trabalho em CTI faz com que, na maioria das vezes, os trabalhadores se esqueçam de tocar, conversar e ouvir o ser humano, ou seja, se esqueçam de interagir com o ser que depende de seus cuidados, utilizando como justificativa para este fato o tempo limitado e o alto número de tarefas a serem realizadas. Este serviço caracteriza-se, principalmente, pela instabilidade de seus 
pacientes, pela agilidade da equipe, pela habilidade técnica e científica dos profissionais, por uma dinâmica ininterrupta, onde o fator tempo faz uma notável diferença na qualidade dos resultados da atenção prestada.

O trabalho neste setor reproduz a lógica do trabalho fragmentado, calcado no modelo clínico ainda vigente, alicerçado na clínica anátomo-patológica, na recuperação do biológico, sendo excluídos do processo do adoecer os aspectos psicossociais do indivíduo. O ser doente é abstraído de seu meio social, sendo sua vida em sociedade esquecida pelos profissionais que prestam o cuidado (LIMA, 1998).

O modelo clínico-biológico, fragmentado, ainda muito utilizado nas ciências da saúde, está alicerçado na recuperação do corpo biológico, na recuperação de apenas uma parte do corpo que apresenta um sintoma específico, excluindo assim, o processo do adoecer os aspectos psicossociais. Aliado a isto se tem um ambiente, por si, hostil, onde os profissionais desenvolvem suas atividades sob forte estresse, o risco de morte de alguns pacientes e pelo ruído intenso dos aparelhos ali utilizados.

A formação profissional alicerçada neste modelo biomédico leva à desarticulação do sentir e agir, o que inviabiliza a formação de profissionais críticos, sensíveis e transformadores (BOEMER; CORREAA, 2003).

Não há como desconsiderar a história de vida do paciente, suas relações e vivências. A maneira como a pessoa vivencia os processos patológicos está intimamente ligada ao seu modo de vida, envolvendo dimensões subjetivas e sociais (URIZZI, 2005).

Este ambiente é também considerado um ponto de destaque na "desumanização" dos profissionais desse serviço de saúde. O freqüente contato com o sofrimento 
humano pode gerar ansiedade e, como conseqüência, o afastamento e dificuldade de interagir com o sujeito em estado crítico (BRASIL, 2006).

Nesse sentido, é fundamental procurar atentar ao ensino desta prática, especificamente, no contexto do CTI eleito para este estudo, no nível técnico profissional, indagando como formar trabalhadores que tenham condições de vir a contribuir para a construção de um cuidado integral, ético e humano no contexto do CTI.

Ao invés de simplesmente imaginar estratégias para tal, um ponto primordial é interrogar o fenômeno "aprendendo a cuidar do doente em estado crítico em terapia intensiva", fazendo uma aproximação com aqueles que o vivenciam no processo de formação, valorizando a subjetividade do aprendiz como elemento fundamental para a compreensão do sentido de sua formação para cuidar nesse contexto: esses trabalhadores estarão apenas reproduzindo o fazer dado? Terão críticas quanto ao cuidado que ali se desenvolve? Estarão sensibilizados para o cuidar humano? Como se sentirão como humanos que cuidam de humanos nesse cenário de aprendizagemtrabalho?

A aproximação das experiências de formação para o cuidar de doentes críticos desses trabalhadores poderá lançar possibilidades sobre tais questionamentos, colocando a própria prática em CTI em foco. Esta aproximação exige um olhar que a direcione - uma abordagem metodológica - e ações que a viabilize - técnicas específicas para coleta de dados - permeadas pela ética. É sobre isso que passo a discorrer no próximo capítulo. 


\subsection{Referencial Teórico Metodológico}

Ao decidir realizar um estudo envolvendo o processo educacional profissionalizante, senti a necessidade de buscar por um método que me permitisse permear as vivências dos sujeitos, em contraposição aos estudos positivistas a que sempre estive acostumada. Encontrando na fenomenologia esta possibilidade, passei a procurar referências que pudessem propiciar meu embasamento teórico.

Ao procurar orientação para esta nova etapa da minha experiência profissional, deparei-me com novos conceitos, adotados principalmente pelas pesquisas sociais, ainda recentes na área da saúde e, também com termos utilizados por algumas abordagens filosóficas, dentre elas a fenomenologia.

Dada a complexidade do método fenomenológico, considero conveniente discorrer sobre a fenomenologia numa primeira aproximação, a fim de não incorrer em erros graves, destacados por alguns autores já reconhecidos. Esta compreensão busca fundamentar esta pesquisa e a pesquisadora.

O argumento fundamental é de que a ação humana é subjetiva. A intenção do comportamento humano, ao contrário dos fenômenos naturais, não pode ser descrita e muito menos explicada com base nas suas características exteriores e objetiváveis, uma vez que o mesmo ato externo pode corresponder a sentidos de ação diferentes.

Toda investigação se inicia por um problema ou interrogação, articulada a conhecimentos anteriores culminando na criação de novos referenciais. Na pesquisa fenomenológica não se explicita problema, no sentido positivista, a ser pesquisado e 
sim a "dúvida", inquietação, do pesquisador sobre alguma coisa e quando há dúvidas é feita a interrogação (MARTINS; BOEMER; FERRAZ, 1990; BICUDO; ESPÓSITO, 1994).

Nesse direcionamento a questão: "como é para o educando (aluno - técnico em enfermagem) cuidar de um doente em estado crítico? Como essa experiência tem se mostrado a ele?".

De acordo com Dartigues (2003), a fenomenologia pode ser entendida como forma de superação das tendências racionalistas e empiristas, rompe com a dicotomia entre razão-experiência, vigente na visão positivista. Tem-se, assim, a idéia de que não há o objeto de conhecimento isolado do sujeito, mas os quais podem ser diversos dependendo da perspectiva pela qual o objeto é visto e de seu contexto.

Durante a trajetória fenomenológica, as vivências do pesquisador são importantes, elas permitem interrogar o mundo e os fenômenos. O pesquisador apreende um conjunto de asserções significativas para ele.

De acordo com Martins (1992), a fenomenologia é percebida como um momento onde o principal objetivo está na investigação direta e na descrição dos fenômenos experienciados pela consciência, não utilizando teorias para explicações causais, ou seja, livre de preconceitos e pressupostos. Para o estudo qualitativo, é importante a presença de um conhecimento pessoal, intuitivo, subjetivo e experiencial.

O enfoque central da fenomenologia é a compreensão dos fenômenos, dirigindose para as vivências do indivíduo, em seu dia-a-dia. A pesquisa fenomenológica na área da saúde deve ser enfocada como uma possibilidade de gerar conhecimentos que, fundamentados na compreensão existencial do homem, contemplem a dimensão humana para além da perspectiva técnico-científica (CORRÊA, 1997). 
Cabe ressaltar que, na década de 1980, as primeiras teses de doutorado e mestrado, seguindo o referencial metodológico da fenomenologia, começaram a ser desenvolvidas, trazendo assim a dimensão existencial do sujeito a quem o cuidado é prestado.

A enfermagem encontra-se em um processo de reexame; a idéia de um universo estático é agora incompatível com o mundo como um processo dinâmico da construção humana. O paradigma das ciências humanas é visto como pertinente para a área da enfermagem, pois possibilita metodologias que podem levar a formas de compreensão da existência humana (CASTRO et al, 2002)

Nesse contexto, a utilização da fenomenologia na enfermagem deu-se enquanto busca de alternativas metodológicas de pesquisa (CORRÊA, 1997).

E, neste projeto, essa abordagem metodológica mostra-se adequada ao voltar-se para a vivência, permitindo o acesso à dimensão existencial do educando que experiencia o cuidado ao doente em estado crítico no contexto da terapia intensiva, considerando que o aprendizado desse cuidar envolve uma relação entre humanos, relação essa que se constrói nos distintos encontros cotidianos, delimitados por um contexto.

Poucos autores (REZENDE, 1989; BICUDO; ESPÓSITO, 1994; COÊLHO, 2002; MARTINS; BICUDO, 2005) trazem a fenomenologia no contexto da educação. Rezende (1989) destaca que o fazer fenomenologia traz já em seu bojo um teor pedagógico, principalmente pelo seu caráter discursivo. Em seu texto, o autor traz a possibilidade de fazer uma filosofia da educação nos moldes fenomenológicos, já que nenhum dos principais teóricos descreveu um "tratado sobre a educação". 
Ele considera educação como um fenômeno, reconhecendo que se trata de uma experiência profundamente humana, todos os homens se educam, e só eles o fazem. $\mathrm{O}$ indivíduo, só ou em grupo, no viver coletivo, está implicado em um fenômeno educacional, isto é, todas as ações humanas são aprendidas no decorrer da existência, tanto nas relações familiares quanto nos grupos sociais em geral. Segundo o autor, "a filosofia tenta compreender o mundo, apreender o seu sentido, da maneira como ele é vivido". Tudo isto diz respeito, à educação.

\subsection{TRAJETÓRIA METODOLÓGICA: O ACESSO AO EDVCANDO}

\subsubsection{O MUVNDO HABITADO PELO EDVCAJNO}

A cidade escolhida para a realização deste estudo fica localizada no interior do Estado de São Paulo e é reconhecida pelo seu pólo educacional, principalmente na área da saúde. Possui nove instituições de ensino profissionalizante em enfermagem cadastradas pela Secretaria Municipal de Educação.

Entretanto, para se obter o acesso do educando em estágio no CTI é preciso autorização da gerência de enfermagem e diretoria clínica da instituição, além da escola oferecer alguns pré-requisitos como número limitado de alunos por grupo, cinco alunos com um enfermeiro supervisor de estágio, condição esta nem sempre atendida 
por todas as escolas profissionalizantes. E, ainda, é necessária a autorização da própria administração do hospital, condição essa nem sempre atingida em meio às negociações entre instituições de saúde e de ensino.

A instituição escolhida é a única pública de ensino profissionalizante em saúde do município, pertence ao Hospital das Clínicas da Faculdade e Medicina de Ribeirão Preto da Universidade de São Paulo (HCFMRP/USP) e participa da formação de profissionais da área de saúde. Seus professores são ligados à instituição hospitalar de referência e visa qualificar a formação dos funcionários da instituição e de outras, sendo reconhecida pelas instituições de saúde da cidade e da região.

O local escolhido para a observação não participativa e posterior coleta de dados foi o Centro de Terapia Intensiva da Unidade Campus do referido hospital, onde os educandos realizam estágio de forma regular. O CTI recebe pacientes de clínicas diversas da instituição, tanto cirúrgicas quanto clínica, comporta nove leitos, além dos cinco leitos destinados ao tratamento de pacientes clínicos de doenças cardiológicas.

Os educandos, sujeitos da pesquisa, pertencem ao curso de técnico de enfermagem do Centro Interescolar do HCFMRP. Este centro foi fundado em 1975 e oferece, além deste curso, outros três da área técnica de saúde, auxiliar de enfermagem, técnico em biodiagnóstico e técnico em radiologia. Forma aproximadamente 140 egressos ao ano. Os educandos exercem suas atividades práticas, estágios, nos diversos setores do hospital, sendo orientados por supervisores enfermeiros habilitados para esse fim.

Em média, as turmas do curso técnico de enfermagem são formadas por trinta interessados, sendo estes divididos em grupos de cinco alunos para inserção nas áreas 
de alta complexidade, proporcionando ao supervisor melhor visão do campo e da sua aprendizagem (HCFMRP/USP, 2005).

Os educandos têm como campo de estágio para o atendimento ao paciente em estado crítico os setores de terapia intensiva do HCFMRP da Unidade Campus e da Unidade de Emergência, além da Unidade de Queimados também pertencente a esta instituição.

Os pertencentes ao grupo em estudo, são auxiliares de enfermagem, funcionários do HCFMRP/USP e de outras instituições de saúde da cidade de Ribeirão Preto, além de egressos do módulo I do curso de Habilitação em Técnico de Enfermagem da mesma instituição e que não exercem atividades como auxiliares de enfermagem.

O histórico escolar do curso possui o módulo I com as disciplinas: Gestão em Saúde, Fundamentos de Enfermagem, Enfermagem Médica, Enfermagem Cirúrgica, Enfermagem Materno-Infantil e Enfermagem em Saúde Coletiva, perfazendo um total de 1.230 horas. No módulo II, parte integrante desta pesquisa consta as disciplinas de Psicologia Aplicada, Higiene e Profilaxia, Saúde Ocupacional, Enfermagem Saúde Mental e Geriatria, Enfermagem Intensivista e em Urgências, Farmacologia para a Enfermagem, Administração em Enfermagem e Informática, comportando um total de 612 horas, dispostas em aulas teóricas e práticas, estas divididas em laboratório e estágio em unidade hospitalar (ANEXO A).

A instituição tem o compromisso de formar profissionais generalistas, com carga horária total de 1.842 horas, em acordo com a Resolução CNE/CEB n . 4/99 (BRASIL, 1999a), destacando em seu perfil as competências (ANEXO B): 
prestar assistência de enfermagem em programas de proteção, de recuperação e de reabilitação da saúde; respeitar e considerar os clientes atendidos, e os que procuram os serviços de saúde; observar as necessidades do paciente sob sua responsabilidade, levando em consideração variáveis tais como: idade, sexo, complexidade do estado de saúde; planejar e organizar o trabalho na perspectiva do atendimento integral e de qualidade, entre outros.

No módulo II o aluno faz primeiramente todo o conteúdo teórico e após essa fase inicia o estágio supervisionado, segundo escala pré-determinada, permanecendo por aproximadamente dez dias em cada campo de estágio: Unidade de Psiquiatria Unidade Campus, Centro de Terapia Intensiva Unidade Campus, Sala de Urgência da Unidade da Unidade de Emergência e Unidade de Queimados da Unidade de Emergência (ANEXO C).

Durante a realização deste estudo realizei a observação dos alunos pertencentes ao Módulo II, durante a passagem pelo Centro de Terapia Intensiva, onde se prioriza o atendimento de pacientes críticos, como citado anteriormente, levando em consideração também a experiência dos alunos em outros locais de estágio ou de trabalho já que suas experiências anteriores se mostram em suas atitudes presentes. 


\subsubsection{A OBSERVAÇÃO NÃO PARTICIPANTE E AS ENTREVISTAS}

A fenomenologia valoriza o estudo da vivência, compreendendo que uma das formas de acesso à experiência do outro se dá pela escuta da sua fala e pelo olhar atentivo à sua ação e aos seus gestos cotidianos. Todas essas formas de expressão se fundamentam em um discurso, um modo de ser no mundo consigo e com o outro (SIMÕES; SOUZA, 1997).

Neste estudo, foram utilizadas duas técnicas para coleta de dados, entre elas a entrevista utilizando uma questão norteadora, ou seja, uma pergunta mais abrangente procurando resgatar as vivências do educando e, a observação não participante pela qual o pesquisador permanece atento à realidade sem nela interferir (MARTINS; BICUDO, 2005).

Ao dizer sem nela interferir não se trata de supor neutralidade ou de se crer que a presença de alguém estranho em nada interfere no agir dos profissionais, mas sim delimitar que como pesquisadora não interferia na prática do cuidado nem no ensino do grupo de estudantes, conforme foram se processando no cotidiano.

Nesse sentido, acompanhei e registrei em um diário de campo, as situações de ensino-aprendizagem vividas pelos alunos do curso profissionalizante de nível técnico em enfermagem do Centro Interescolar do Hospital das Clínicas da Faculdade de Medicina de Ribeirão Preto da Universidade de São Paulo (HCFMRP/USP), no contexto da terapia intensiva da mesma instituição na Unidade Campus. 
Esse acompanhamento se deu de 30 de julho a 11 de outubro de 2006. De modo geral, permanecia três horas durante o plantão noturno, período destinado ao estágio. Pude acompanhar três turmas, cada uma com cinco alunos durante todo o período de estágio.

Ainda com a intenção de adquirir mais elementos que possibilitassem compreender a experiência do aluno em seu contexto, entrei em contato com o programa da disciplina/estágio, para elucidar os objetivos e desenvolvimento do processo ensino-aprendizagem conforme proposto pela escola.

Durante o período de observação não participante, estive no CTI apenas como pesquisadora e não como supervisora do estágio, permitindo que o processo ensinoaprendizagem voltado ao cuidado do doente crítico pudesse se mostrar em algumas perspectivas, a partir das expressões dos alunos, das relações que estabeleceram, de suas verbalizações e gestos. Para isto não utilizei um roteiro pré-elaborado, mas uma observação atenta em todos os momentos do estágio.

Ao optar pela observação não-participante em um CTI, a intenção foi acompanhar o aluno no cuidado ao doente crítico, transcrevendo suas atitudes ao se deparar com o doente que necessita de cuidados.

Minha visão no início estava centrada no cuidado técnico e em sua relevância para a enfermagem. Ao conhecer um pouco os conceitos da literatura fenomenológica e durante o transcorrer desta minha observação percebi o quanto esta visão era limitada, percebi que a mecanização do atendimento de enfermagem também estava presente na minha formação, apesar de não percebê-la. Assim, esta percepção possibilitou-me desvelar além do ponto onde estava antes. 
Fez-se necessário por vezes meu afastamento do campo por sentimentos que, em certo momento, atrapalhavam a tarefa proposta e também, por haver uma convergência das situações vividas pelos alunos e pela supervisora, mesmo as histórias de vida dos alunos sendo tão diferentes.

Cabe mencionar aqui a colocação de Santos (2005), na qual o pesquisador ao utilizar a abordagem qualitativa deve estar engajado ou fazer parte do fenômeno social que ele pretende compreender, exigindo, portanto, uma convivência e um contato íntimo com a realidade em que se insere o fenômeno em estudo.

O pesquisador, na abordagem qualitativa, se dirige ao local de estudo, pois a preocupação é com o contexto, a ação é mais bem entendida quando observada no local em que ocorre. O elemento chave da análise é a compreensão obtida através dos dados daquela realidade (SANTOS, 2005).

Por observação entende-se, em acordo com Ludke e André (1986), um local privilegiado de coleta de dados na pesquisa educacional, possibilitando um contato pessoal do pesquisador com o fenômeno pesquisado. Essa técnica permite que o pesquisador aproxime-se do sujeito, do fenômeno a ser pesquisado, na tentativa de apreender o significado que eles atribuem à realidade que os cerca e às suas ações.

O estágio que acompanhei pertence à disciplina de Enfermagem Intensivista e em Urgências, com uma carga horária total de 76 horas, sendo 40 horas de aulas teóricopráticas e 36 horas de estágio supervisionado. Acho oportuno salientar que o período destinado ao estágio, foi dividido igualmente entre as disciplinas de Administração em Enfermagem, Enfermagem em Saúde Mental e Geriatria e Neurologia.

Uma parte da disciplina de Administração em Enfermagem deu-se como primeiro momento do período de estágio dos alunos ocupando assim quatro dias do primeiro 
grupo em CTI e consistia na resolução de um questionário pelo grupo envolvendo questões de distribuição de pessoal, função dos membros da equipe, distribuição do trabalho em CTI e necessidades quanto à aquisição e controle de material permanente e descartável pelo serviço. Após a realização do mesmo foi destinado um dia do estágio para apresentação de todos os grupos em sala de aula.

Durante a apresentação foram expostas pelos grupos em forma de seminários as características principais de cada campo de estágio: Unidade de Queimados, Unidade de Psiquiatria, Sala de Estabilização e Atendimento de Politraumatizados e o Centro de Terapia Intensiva. Os grupos relataram sua primeira impressão do campo e o que estavam aprendendo nestes setores específicos.

Em nenhum momento foram relatadas as questões do questionário preenchido, ou discutido o trabalho do técnico de enfermagem na administração em enfermagem. Os alunos apenas relataram que a realização da escala é um procedimento difícil de ser executado, principalmente na instituição em que tiveram a oportunidade de conhecer, levando em consideração o número de funcionários disponível e a carga horária peculiar.

Na medida em que fui acompanhando o estágio, pude firmar maior vínculo com os educandos, a partir de meu interesse genuíno em sua experiência de aprendiz do cuidado. Minha intenção foi também a de conversar com eles a respeito da sua experiência, agendando entrevistas individuais conduzidas pela questão norteadora: "Conte-me como tem sido cuidar de doentes em estado crítico nesse momento de sua formação".

As onze entrevistas realizadas foram agendadas conforme disponibilidade do entrevistado, em local determinado por ele, onde o mesmo considerou melhor para se 
expressar, apenas com a ressalva de que fosse realizada na cidade de Ribeirão Preto. Procurei atentar-me quanto aos horários, a fim de não prejudicar seu compromisso escolar e profissional, deixando em aberto o tempo de duração das entrevistas. Em média cada entrevista despendia um período entre quinze a vinte minutos e, eram realizadas ao final do estágio.

Alguns participantes optaram por realizar a entrevista no próprio CTI, em período de intervalo do estágio ou no último dia onde comumente a supervisora destinava um tempo maior para discussão e assinatura dos cadernos onde os procedimentos ali realizados deveriam ser escritos.

Em uma entrevista fenomenológica, é essencial que o entrevistado se sinta à vontade e tranqüilo para expor seus pensamentos e sentimentos. Consideramos adequado, o supervisor de estágio, a coordenadora da escola, minha orientadora e eu, a fim de facilitar minha presença junto aos alunos em campo de estágio, realizar a apresentação do projeto desta pesquisa no momento da apresentação dos seminários da disciplina de administração citada anteriormente, esse momento foi também destinado ao esclarecimento de dúvidas dos educandos e supervisores.

Além de favorecer minha aproximação ao cotidiano dos alunos, também foi importante para exercitar meu papel como observadora em uma perspectiva diferente da habitual, o que envolve não buscar exatamente "isto ou aquilo", mas permitir que a realidade como trama de relações, que se configura em um cenário específico, se mostre naquilo que for significativo, considerando meus questionamentos e a proposta compreensiva do estudo.

Cabe salientar que o estudo não tem a intenção de julgar programas, modos de ensinar e cuidar, reconhecendo as instituições envolvidas, escola e hospital, como 
parceiras no processo de construir conhecimento a partir do cotidiano vivido por um trabalhador que é fundamental no processo de trabalho em saúde, mas a partir deles refletir, questionar, compreender e abrir perspectivas no sentido da educação que possibilite o cuidado.

Para Martins e Bicudo (2005), a entrevista na abordagem fenomenológica é considerada como "um encontro social", com características peculiares como a empatia e a intersubjetividade. Os gestos, movimentos, olhares, entonação da voz e mesmo o silêncio são formas de "vivenciar" o mundo que o sujeito expressa e que têm íntima relação com as faces que estão sendo desveladas do fenômeno em questão.

Durante a entrevista de abordagem fenomenológica destaca-se a percepção do pesquisador em relação à linguagem falada e não falada do pesquisado (SIMÕES; SOUZA, 1997).

\subsubsection{PRECEITOS ÉTICOS}

Ao iniciar a proposta deste estudo, entrei em contato com os coordenadores do Centro Interescolar do HCFMRP-USP e do CTI explicitando o objetivo da pesquisa, bem como meu compromisso em divulgar os dados obtidos, com o intuito de contribuir para a formação dos profissionais técnicos de enfermagem e conseqüentemente do cuidado ao doente em estado crítico. 
Após o consentimento dos coordenadores, o presente estudo foi submetido à avaliação e conseqüente aprovação do Comitê de Ética em Pesquisa em Seres Humanos do HCFMRP-USP (ANEXO D) conforme a Resolução n. 196/96 do Conselho Nacional de Saúde que trata da pesquisa com seres humanos (BRASIL, 1996b).

Os alunos que aceitaram participar deste estudo foram orientados a assinar o Termo de Consentimento Livre e Esclarecido (APÊNDICE A) e tiveram sua identificação resguardada durante a divulgação do trabalho.

Além disso, foram realizados esclarecimentos quanto à liberdade de se retirar a qualquer momento do estudo, sem quaisquer prejuízos e que sua participação não apresentaria qualquer relação com a avaliação realizada pelo docente responsável.

Somente após o aval do Comitê de Ética, dei início ao desenvolvimento da coleta de dados propriamente dita, ou seja, a aproximação com os educandos de nível médio em enfermagem e a realização da observação não participante e das entrevistas.

\subsubsection{A COMPREESS ÃO DO MUNDO HABIADO PELO EDVCANDO}

A compreensão dos dados obtidos foi realizada a partir de delineamentos trazidos por Martins e Bicudo (2005) que enfocam as seguintes etapas: leitura geral do relato ou entrevista, buscando familiarização com o que está sendo exposto; releitura dos textos para que sejam identificadas unidades de significação, focalizando o fenômeno pesquisado; e, finalmente o reagrupamento dos elementos relevantes, para que os 
dados sejam sempre examinados e questionados amplamente de forma a ajudar o pesquisador a manter o foco de atenção o tempo todo, sem esquecer a multiplicidade de sentidos que podem estar implícitos no material.

Cabe ressaltar que tal reagrupamento facilitou a construção de três grandes temáticas: Aproximação do educando ao mundo técnico da terapia intensiva; O emergir da sensibilidade do educando no mundo técnico do CTI; O aprendizado do cuidar do outro em CTI.

Este reagrupamento foi realizado somente para a apresentação do estudo, com a intenção de melhor articulação dos dados e para facilitar a compreensão proposta de maneira mais abrangente e integradora. 
5. DESCRIÇÃA E COMPREENSÃO DA EXPERIÊTCIA 


\subsection{Apresentando os educandos pertencentes ao grupo em estágio no CTI}

A classe do curso observada era composta por trinta estudantes, que se dividiram em seis subgrupos de cinco elementos cada, para a realização do estágio em CTI. Foi possível, assim, a aproximação com quase todos os alunos, pois, algumas pessoas do grupo não foram encontradas após o estágio enquanto outras informaram não ter tempo disponível para o encontro.

Foram realizadas onze entrevistas, sendo esse conjunto constituído exclusivamente de mulheres, não por decisão prévia, mas por estarem disponíveis para encontros posteriores.

A faixa etária dessas estudantes está entre 20 - 40 anos, sendo cinco entrevistadas entre 30 - 40 anos e seis entre 20 - 30 anos. Quanto à escolaridade, todas as entrevistadas possuem o ensino médio completo e cursaram o auxiliar de enfermagem, prerrogativas para a realização do curso técnico. Somente uma delas concluiu o curso de auxiliar de enfermagem há mais de dois anos, as outras concluíram o módulo I no próprio Centro Interescolar e já ingressaram no módulo II para obtenção da Habilitação como Técnico de Enfermagem.

Seis das entrevistadas trabalham como auxiliar de enfermagem atualmente, sendo cinco em uma instituição pública e uma em instituição particular de saúde. Uma dessas alunas estava em período de experiência em CTI de uma unidade pública de saúde especializada no atendimento de "urgências e emergências", enquanto, as outras exercem suas funções em unidades de enfermaria e de ambulatório. Outra aluna 
entrevistada referiu que trabalhou como auxiliar de enfermagem em CTI neonatal de uma maternidade particular deste município, mas há seis anos não trabalha na área.

Para melhor compreensão das entrevistas descrevo algumas características das entrevistadas.

- Aluna 1: (28 anos) trabalha como auxiliar de enfermagem no Serviço de Transplante de Medula Óssea do mesmo hospital onde realizou o estágio. Tem experiência profissional há um ano.

- Aluna 2: (26 anos) trabalha como auxiliar de enfermagem em Ambulatório da instituição onde realizou o estágio há pouco menos de um ano.

- Aluna 3: (22 anos) fez o primeiro módulo do Curso de Habilitação Profissional de Técnico de Enfermagem, tendo o certificado de Auxiliar de Enfermagem. Refere não ter tido ainda a oportunidade de atuar na área da saúde, sua maior experiência com o cuidado foi em estágios.

- Aluna 4: (25 anos) fez o primeiro módulo do Curso de Habilitação Profissional de Técnico de Enfermagem, tendo o certificado de Auxiliar de Enfermagem. Refere não ter tido ainda a oportunidade de atuar na área da saúde, sua maior experiência com o cuidado foi em estágios. Trabalha no comércio.

- Aluna 5: (31 anos) já atuou como auxiliar de enfermagem em berçário e UTI neonatal em uma maternidade particular do município de Ribeirão Preto. Refere não atuar na área da saúde há cerca de seis anos por motivos familiares.

- Aluna 6: (36 anos) fez o primeiro módulo do Curso de Habilitação Profissional de Técnico de Enfermagem, tendo o certificado de Auxiliar de Enfermagem. Refere 
não ter tido ainda a oportunidade de atuar na área da saúde, sua maior experiência com o cuidado foi em estágios.

- Aluna 7: (35 anos) trabalha como auxiliar de enfermagem em Enfermaria de Ortopedia da mesma instituição onde realizou o estágio.

- Aluna 8: (20 anos) fez o primeiro módulo do Curso de Habilitação Profissional de Técnico de Enfermagem, tendo o certificado de Auxiliar de Enfermagem. Durante o período de estágio estava em período de experiência como auxiliar de enfermagem em CTI da Unidade de Emergência do HCFMRP/USP.

- Aluna 9: (20 anos) fez o primeiro módulo do Curso de Habilitação Profissional de Técnico de Enfermagem, tendo o certificado de Auxiliar de Enfermagem. Refere não ter tido ainda a oportunidade de atuar na área da saúde, sua maior experiência com o cuidado foi em estágios. Trabalha no comércio.

- Aluna 10: (34 anos) trabalhou como auxiliar de enfermagem em uma Maternidade Filantrópica do município de Ribeirão Preto, atualmente trabalha como auxiliar de enfermagem no Serviço de Ginecologia e Obstetrícia da mesma instituição que realizou o estágio.

- Aluna 11: (38 anos) fez o primeiro módulo do Curso de Habilitação Profissional de Técnico de Enfermagem, tendo o certificado de Auxiliar de Enfermagem. Atualmente trabalha como auxiliar de enfermagem em um hospital privado do município de Ribeirão Preto em unidade de enfermaria, não referiu há quanto tempo.

\subsection{Apresentação das temáticas}




\subsubsection{Aproximação do educando ao mundo técnico da terapia intensiva}

O estágio do curso para formação de técnicos de enfermagem realizado em CTI, apresentava uma rotina bastante particular. O tempo médio de permanência dos alunos era de dez dias, sendo esses divididos da seguinte forma: o primeiro dia era destinado ao reconhecimento do ambiente; o supervisor apresentava a estrutura física do CTI, posicionamento dos leitos, locais onde os alunos poderiam encontrar os materiais que fossem necessários, os impressos utilizados, folha de controle hídrico, folha de registro de sinais vitais, prescrição médica e prescrição de enfermagem e como deveriam ser preenchidos. Os alunos também obtinham algumas informações, mesmo que de forma rápida e superficial, a respeito dos equipamentos ali utilizados como: respiradores, monitores e bombas de infusão.

Do segundo ao nono dia, o professor aguardava a chegada de todos os alunos e, após isso, selecionava qual ala de internação estava mais calma, ou seja, com pacientes menos graves ou estáveis. Posteriormente, era realizada a passagem de plantão pelo auxiliar de enfermagem responsável pelos pacientes escolhidos. Eram relatadas aos alunos intercorrências ocorridas durante o dia, diagnóstico médico do paciente, cuidados especiais e exames a que os pacientes seriam submetidos naquela noite bem como medicamentos que eles fariam uso.

Os alunos então eram divididos em dupla e/ou trio pelo supervisor e recebiam orientações suplementares, tais como: quem seria o responsável pela anotação de enfermagem naquele dia, pela medicação, pela realização de procedimentos de 
enfermagem além de orientações sobre como manusear cateteres, monitores e respiradores, ou quaisquer aparelhos utilizados.

O último dia de estágio era destinado à avaliação do estágio, na qual os alunos tinham a oportunidade de comentar sobre como havia sido aquele período. $\mathrm{O}$ supervisor realizava uma breve explanação a respeito da evolução do grupo e assinava os cadernos de procedimentos, material este disponível a todos e onde eram destacadas as técnicas aprendidas previamente em laboratório que haviam sido realizadas naquele campo.

Esta forma de organizar a atividade do estudante é marcada pela fragmentação do cuidado técnico, sendo muito utilizada em estágios, principalmente no ensino profissionalizante, em vista da pouca oportunidade de desenvolver as atividades pertinentes à função do técnico de enfermagem como, por exemplo, a prática de procedimentos invasivos, daquele serviço. Todavia, o aluno sabe que em terapia intensiva, o cuidado é realizado por um único profissional, que, muitas vezes, é responsável por dois ou três doentes, dependendo da gravidade de cada um deles.

OCha, lá (na escola) a gente aprendeu teoria, mas aqui na prática, a gente tá vendo melhor, porque se eu demorar com um paciente, e aqui a gente fica dois (alunos) pra um (paciente), imagina se eu cair aqui dentro, e tiver que cuidar de três de uma vez, eu vou acabar que horas, uma hora da tarde? $\mathcal{E}$ as anotações, e os remédios (...) aqui você fica ouvindo e põe em prática o que tá falando. É melhor. (A4)

Nesse sentido, o trabalho nessa unidade não mais se organiza pela divisão das tarefas a serem executadas por diversos profissionais de enfermagem e o estudante tem noção disso. 
Embora esse tipo de organização do trabalho busque a melhoria da qualidade do atendimento e seja entendido, por muitos profissionais, como a realização do cuidado integral, este termo (integral) é utilizado, a meu ver, de forma dúbia.

Garantir que uma única pessoa execute todas as tarefas não significa necessariamente cuidado integral. A assistência integral ao doente é percebida pelo profissional de enfermagem, na prática hospitalar, como o modo de organizar o trabalho no qual um único profissional torna-se responsável pelo paciente ou por uma enfermaria, prestando todos os cuidados necessários a eles.

O termo cuidado integral, entretanto, refere-se ao cuidado do ser humano em suas dimensões biológica, psicológica, social e espiritual, isto é, de uma pessoa com modos de ser e agir próprios inseridos em um contexto social. Isso implica considerá-la permanentemente nas relações que constrói (ou não) em sua vida, consigo mesmo, com a família, com o trabalho e comunidade.

Ao observar a forma como o cuidado em CTI, ou mesmo em outros serviços de saúde, é realizado, percebo a preocupação em resolver um único problema, a doença do indivíduo, ou ainda apenas a tarefa, como a realização de um curativo, um banho ou aferir e anotar os sinais vitais, naquele momento e da forma mais ágil possível.

De acordo com Boemer e Corrêa (2003), o atendimento em saúde ainda é centrado na execução de técnicas e tarefas que fragmentam e objetivam o ser humano, reduzindo-o a portador de uma patologia específica. Faz-se necessário, nessa ótica, compreender o doente em outra perspectiva, para além de simples depositário do cuidado em saúde.

O supervisor do estágio refere-se ao cuidado não em sua complexidade, mas à realização de procedimentos pontuais, que mesmo do ponto de vista biológico podem 
não se integrar, até porque há dificuldade do aluno, ainda sem experiência e agilidade, em cuidar do paciente crítico, tendo em vista o elevado número de procedimentos a serem realizados em um curto espaço de tempo.

Os próprios estudantes questionam se seriam capazes de prestar atendimento "integral", ou seja, se seriam capazes de realizar todos os procedimentos pertinentes em um ou mais pacientes, em um período de seis horas, como está dividido o plantão na instituição por eles conhecida. Esse seu questionamento, como já comentado, reduz a complexidade do cuidado integral, afastando-se da possibilidade de cuidar em terapia intensiva para além do procedimento, já que o modo de pensar do educando não é trazido à reflexão.

Cabe ainda considerar que o cuidado integral é prerrogativa do SUS, estando associado não apenas ao olhar ampliado que considera as dimensões biológica, psicológica e social do usuário como também à articulação dos distintos níveis de atenção e das ações de prevenção, promoção e tratamento na organização do sistema de saúde.

Assim, no contexto da terapia intensiva, o aprendizado do educando de enfermagem não contempla a sua compreensão do CTI como parte de um sistema mais amplo. Portanto, o cuidado integral da pessoa gravemente doente também depende das articulações desse setor com os demais níveis de atenção e da ampliação do modo de cuidar em terapia intensiva para além da técnica e dos parâmetros biológicos, sabendo-se que ali há um ser físico, social e subjetivo demandando cuidado.

Todavia, o que predomina e é reproduzido no contexto da educação profissional é a limitada contextualização, bem como a incipiente consideração da afetividade e subjetividade. 
O programa de aulas teóricas é ainda muito focado no fazer técnico incluindo a fisiopatologia de diversas doenças, planta física e estrutura do CTI - características gerais e dimensionamento dos recursos humanos e equipamentos. Entretanto, a questão do CTI no contexto da saúde atual, a valorização do ser humano e a humanização da assistência são lembrados apenas em conversas informais entre alunos e professores.

O currículo explicita a operacionalização do ensino de conhecimentos, habilidades e valores. A partir da Lei de Diretrizes e Bases da Educação Nacional (LDB), de 1996, a elaboração do currículo passa a ser de responsabilidade da escola e deve ser concebida com a participação efetiva de professores, à luz do próprio projeto pedagógico. O conteúdo do currículo deve condizer com o perfil do aluno a ser formado pela instituição, levando em consideração as competências profissionais gerais do técnico firmadas em lei específica (BRASIL, 1996a).

A forma como o aluno se coloca frente ao doente dá a entender a concepção do cuidado de enfermagem. Parece que o comportamento dos integrantes da equipe é permeado pela concepção de que cuidar é executar procedimentos técnicos de alta complexidade, e o envolvimento e a afetividade não precisam ser necessariamente considerados (DUPAS; PAVARINI, 1999).

Isso também remete a um modo de cuidar que aniquila o outro como ser de liberdade que mesmo gravemente doente não se iguala a objetos manipuláveis. Estar restrito ao leito e impedido de falar e movimentar-se, tendo seu corpo entregue ao profissional da saúde, a pessoa doente do ponto de vista existencial preserva a dimensão de liberdade. $\mathrm{E}$ isso precisa ser cuidadosamente considerado pelo profissional (CORRÊA, 2000). 
É necessário transformar a relação com o doente, o que implica em conceber o profissional de saúde como agente que pode responsabilizar-se pela sua prática, não apenas com tarefas parcelares a serem cumpridas. De acordo com Boemer e Corrêa (2003, p. 264) "como um fazer essencial que se integra no atendimento ao cidadão, exigindo, além da competência técnica, capacidade crítica, criatividade, sensibilidade e compromisso".

O ser humano, profissional de enfermagem, ao se relacionar com o outro, ser doente, pode imprimir ao atendimento em saúde, uma face humana que se traduz em atitudes de confiança e acolhimento (BOEMER;CORRÊA, 2003).

Porém, a prática tecnicista do ensino profissionalizante é entendida como objeto de aprendizado, em detrimento das relações humanas e da percepção crítica do cidadão, que pode gerar a alienação do futuro profissional. A rotina do CTI pode restringir a percepção do educando, principalmente pelo incrível aparato tecnológico ali existente (HAYASHI; GISI, 2000).

Há o predomínio de uma relação desigual entre o profissional de saúde, detentor do saber técnico-científico que se impõe ao "cliente", e este objeto de saber, suas receitas, ordens, cuidados e conselhos. Essa situação acaba por fortalecer uma cultura profissional que valoriza o "paciente" (BOEMER; CORRÊA, 2003).

Os pacientes em CTI, muitas vezes, ficam impedidos de falar, de se expressar com maior clareza, em virtude da presença de tubos, aparelhos de ventilação artificial, sedação, coma, dentre outros aspectos, perdendo o poder de controlar o seu próprio corpo quanto aos cuidados diários de higiene, vestimenta, alimentação, movimentação. Trata-se de uma sujeição total ou quase àqueles que cuidam (CORRÊA, 1998). 
No contexto do CTI uma idéia parece ser fundamental: apesar da alta densidade tecnológica da terapia intensiva, o que tornaria mais difícil o aprendizado dos estudantes, o cuidado do doente crítico é considerado "mais fácil” por eles.

Essa ambigüidade que o trabalho do CTI traz, ou seja, apesar de altamente tecnológico, dá a impressão de que é mais fácil o cuidar, é mostrada pelo depoimento dos alunos entrevistados e por falas ditas no próprio cenário hospitalar, como: é mais fácil cuidar no CTI, o paciente do CTI é mais fácil que o da enfermaria, prefiro o paciente entubado. Mesmo em meio às dificuldades na realização de procedimentos por ser o paciente mais instável e as técnicas altamente invasivas, a pessoa torna-se manipulável, aos olhos do profissional, e não faz exigências ou questionamentos a respeito do seu tratamento.

Assim, é reduzida à idéia que relaciona as práticas desumanizantes com a presença do aparato tecnológico, pois o que se faz essencial é sim o cuidar do outro como objeto, coisa, não sendo considerada a sua natureza e dignidade humana.

As falas dos alunos mostram claramente, a maior facilidade em cuidar do doente crítico. A idéia da sujeição e manipulação do outro pode estar nas entrelinhas.

É uma experiência bem diferente, é um paciente que parece ser mais fáciᄃ porque é um paciente que você pode fazer as coisas, sem medo. SNão porque ele não pode reclamar, porque a gente não vai fazer as coisas de qualquer jeito, mas é mais fácil do que com um paciente que está na enfermaria (A.9)

Quando eu vim trabalhar aqui (no $\mathcal{H C}$ ) tinha a vaga pro $\mathcal{T} M$ O pro CTI, mas imagina, eu tinha medo, assusta (...) então eu escolfi o TMMO. Se fosse hoje eu escolheria trabalhar lá (CTI), é mais fácil, tem um monte de aparelhos, mas é mais gostoso.(A1) 
Rocha et al (1996, p.100), realizaram uma investigação a respeito da resistência da equipe de enfermagem em assistir pacientes conscientes em CTI. Os técnicos e auxiliares entrevistados relatam que preferem trabalhar com pacientes inconscientes que demandam a execução de vários procedimentos, considerando que assim o tempo passa mais depressa.

O paciente quando acordado é fonte de estresse para os alunos, pois questiona mais, reclama da demora de um procedimento ou não aceita um cuidado. Estando ele sedado ou inconsciente, essa fonte de estresse não existe mais, pois parece haver ali somente um corpo para ser higienizado ou receber algum outro tipo de cuidado, ou seja, há uma significativa redução do homem doente.

Se o paciente acordado pode ser fonte de estresse, isso revela o qüão difícil é para o aluno escutar, dialogar, negociar, habilidades essas essenciais para o cuidado humano. Lidar com o outro como sujeito implica em aprender outros modo de relacionar-se e, sobretudo, compreender a pessoa doente. De qualquer modo, essa dificuldade de estabelecer o contato humano com alguém que fala, exige, não é claramente apontado pelo aluno, como é o receio da técnica.

É preciso considerar que tal medo é legítimo; o aprendizado técnico também é difícil e tem sérias implicações. A questão a ser colocada é: como aprender a ser um excelente técnico, imprescindível no cuidar, sem que a técnica seja o único recurso para cuidar do outro?

Corrêa (1995) discorre que o estado de gravidade do paciente e a complexidade das ações nessa condição, parecem determinar uma prática mecanicista. De um modo geral, predomina o cuidar do ser humano como vida biológica, sendo a competência 
técnica muito valorizada. No contexto da terapia intensiva, recuperar a saúde tem o significado de recuperar a vida e isto dá ao trabalho do profissional cunho de importância.

Isso mostra o quanto a técnica em si mesma é valorizada nesse contexto e reproduzida na formação dos técnicos de enfermagem.

Para os alunos entrevistados neste estudo, o CTI é um local onde podem ser executadas várias técnicas, e por isso, promove o aprendizado e sua formação, sendo facilitador quando em processo de seleção para emprego.

Bom foi uma experiência 6oa, porque eu não tenho experiência de trabalho nenhum, nunca trabalhei, assim, uma semana, quer dizer 20 dias atrás, eu deixei de ser contratada por falta de experiência em CTI, então (...) foi 6om. (A. 6)

Foi muito bom passar lá (CTI) para agora poder escolher melhor onde a gente pode trabalhar conhecer mais lugares é muito 6om. (A 2)

Depois que você trabalha aqui trabalha em qualquer lugar (A 5)

(...) eu sei que aprendi 6astante, assim, pra que serve que cuidados eu tenho que ter com o ventilador, o que faz essa medicação, o que uma patologia faz com uma pessoa (...) apesar de já trabalhar (como auxiliar) eu não entro em contato com isto, $e$ é um cuidado que se você não passar por isto, você não sabe qual atitude certa tomar numa situação dessas (...) (A7)

(...) foi 6om, aprendi muita coisa (...) tentei, pelo menos assim, me aplicar, fazer bastante coisa que eu nunca tinha feito, me envolver com o trabalho, assim gostei (..), aspiração de traqueostomia, mexer com bomba de infusão, eu nunca tinha colocado a mão, assim mexer mesmo (...) e agora tive essa experiência.(A. 6) 
Em outro estudo (CARVALHO et al, 1999), foram analisadas as expectativas dos estudantes de graduação em enfermagem em seu primeiro estágio no hospital. O aprendizado técnico ganha destaque e aparece como fonte de ansiedade para $81,8 \%$ destes estudantes, ansiedade essa relacionada ao medo de errar e prejudicar o paciente.

Algumas falas do presente estudo têm a mesma direção,

É tudo mais complicado, você tem que ter uma atenção dobrada, o paciente pode parar de uma hora pra outra, por causa de um simples errinho, de uma falta de atenção de segundos, da gente né? Tem que dar todas as medicações no horário certo, na dose certa, então é complexo, é complicado. (A. 11)

chega em casa e fica preocupada se fez todas as medicações, se passou tudo no plantão, e que até sonha com respirador, com os pacientes (...) (A.2)

eu sempre trabalhei com criança, berçário, VTI neo natal, eu gosto dessa área, (...) porque eu tinha medo de trabalhar com adulto, vou ser sincera, eu tinha medo, porque é diferente, só em estágio né? (...) você fica com receio de fazer, fica assim, será que eu vou errar, será que eu vou fazer direito.(A.5)

Ao mesmo tempo em que parece existir a idéia de que o domínio técnico garantirá a atuação profissional, a técnica amedronta o educando, sua preocupação em aprender todos os procedimentos também deve ser vista como um modo de preocupar-se com o outro. Não querer ferir ou prejudicar outrem é importante para o cuidado integral e para a busca da qualidade do atendimento.

Talvez fosse interessante ao educador auxiliar o educando a manter a preocupação genuína com a segurança do outro, aprendendo a realizar a técnica sem, 
contudo, transformá-la na finalidade do cuidado, considerando-a apenas como mais um recurso a ser utilizado com competência.

Casate e Corrêa (2006) relatam as vivências de alunos de graduação em enfermagem em estágio hospitalar e, encontrando situações de ampla valorização do fazer técnico pelo estudante questionam sobre até que ponto a formação de profissionais de saúde vêm dando conta de favorecer o desenvolvimento de competência que contemple uma assistência integral ao homem, considerando sua complexidade e singularidade.

Outra faceta que se revela na fala do educando deste estudo, ilustrada a seguir, é a que considera esse estágio como uma repetição dos "cuidados" aprendidos anteriormente, sem negar a oportunidade de resolução de algumas dúvidas, a saber:

(...) eu já tinha tido contato com paciente no auxiliar de enfermagem, tô achando a mesma coisa, não tô vendo nada de diferente (...) a única novidade é a parte da administração que eu nunca tinha visto. O restante por enquanto tá sendo a mesma $\operatorname{coisa}($ A. 3)

(...) não foi traumatizante porque eu já conhecia tudo, tava familiarizada com tudo aquilo, né? As bombas, eu já sabia o que era uma bomba de infusão, um respirador, mais ou menos eu sabia,(...) mas eu tive a oportunidade de aprender mais, eu tinha a professora do meu lado e podia perguntar tudo o que eu ainda tinha dúvida (...), agora as técnicas eu já sabia (...) (A. 8).

Elas mostram que existe falta de compreensão no que diz respeito às diferenças do trabalho do técnico e do auxiliar de enfermagem, que se reproduzem na forma como é dado todo o processo ensino - aprendizagem. Ao encontrar expressões como "não tô 
vendo nada diferente" ou "eu já conhecia tudo" pode-se questionar como está sendo visto o trabalho desses profissionais até mesmo pelos professores. Estarão os estudantes apenas cumprindo tarefas?

Santos e Cassiani (2000) procuram mostrar a ambigüidade de sentimentos e ações manifestadas por docentes do ensino profissionalizante. As autoras referem-se às dificuldades citadas pelos docentes quanto à falta de diretrizes ao se delimitar o perfil do futuro profissional.

Esta indefinição está mais ligada à atuação do técnico de enfermagem, devido à sua própria situação no mercado de trabalho, no qual não estão claramente diferenciadas as suas funções em relação às do auxiliar de enfermagem. No estudo acima citado, o próprio docente se questiona: até onde vai o trabalho do auxiliar? Até onde vai o técnico? O ensino deste profissional é visto por ele como um desafio.

As Diretrizes Curriculares Nacionais para a Educação Profissional expressas na Resolução CNE/CEB n. 04/1999 e Parecer CNE/CEB n. 16/1999 destacam que:

para o planejamento do curso, a escola deverá considerar as Diretrizes Curriculares Nacionais para a educação profissional de nível técnico e utilizar como subsídios os referenciais curriculares por área profissional elaborados pelo MEC; a experiência desenvolvida pela própria escola e seus profissionais; as pesquisas e estudos existentes ou de iniciativa da escola; a legislação referente ao exercício profissional; as classificações ocupacionais; as consultas e parcerias com empresas e organizações, com órgãos de classe e de profissionais, bem como o conhecimento consolidado por outras instituições de educação profissional e seus docentes e técnicos (BRASIL, 1999a; BRASIL, 1999b).

E ainda, 
área profissional da saúde compreende as ações integradas de proteção e prevenção, educação, recuperação e reabilitação referentes às necessidades individuais $e$ coletivas, visando a promoção da saúde, com base em modelo que ultrapasse a ênfase na assistência médico-hospitalar. A atenção e a assistência à saúde abrangem todas as dimensões do ser humano - Giológica, psicológica, social, espiritual, ecológica -e são desenvolvidas por meio de atividades diversificadas.

Entre as competências profissionais gerais do técnico da área da saúde, a Resolução CEB no. 4/99 dispõe: "identificar os determinantes e condicionantes do processo saúde - doença e; planejar e organizar o trabalho na perspectiva do atendimento integral e de qualidade" (BRASIL, 1999a).

Nesse mesmo parecer acima citado, é comentada a necessidade de revisão dos currículos tanto da educação básica quanto da educação profissional, já que é exigida do trabalhador maior capacidade de raciocínio, autonomia intelectual, pensamento crítico, iniciativa, capacidade de resolver problemas.

Se o aluno não percebe quaisquer modificações em seu curso atual técnico, quando o compara à formação de auxiliar de enfermagem, estará sendo desenvolvida que tipo de formação? Desenvolver consciência crítico-reflexiva e não apenas reproduzir a prática cotidiana supõe outros modos de aprender, seja no cenário da sala de aula ou do serviço de saúde. Além disso, formar para a perspectiva de cuidado integral também exige mudanças curriculares e na prática pedagógica do educador.

A formação de nível médio configura-se como algo extremamente preocupante e desafiador, se observadas as especificidades e peculiaridades que caracterizam o trabalho em saúde, tais como: a preservação da vida, o convívio permanente com o 
risco de morte, o desenvolvimento da autonomia e cidadania, a visão ampliada do ser humano e dos serviços de saúde.

Tais especificidades e peculiaridades demandam transformação como romper com a forte orientação biologicista dos conteúdos selecionados como válidos e significativos, com o enfoque baseado na repetição de técnicas ou na execução de ações automatizadas, enfim, com a reprodução acrítica do cotidiano.

O contato do aluno com a rotina hospitalar diária permite que ele conheça e identifique as atividades que permeiam a prática assistencial e a maneira de se fazer enfermagem. Entretanto, o modo como a prática se mostra é a mais adequada se a intenção é a formação para o cuidado integral?

A inovação reside em mudar a maneira como o ensino é direcionado, focando metas para a educação ao invés do simples treinamento de rotinas a fim de se alcançar a compreensão do outro e do cuidado, levando o aluno ao desenvolvimento da consciência crítica (ZEM -MASCARENHAS; BERETTA, 2005).

Cabe ainda destacar que na formação do técnico de enfermagem, é incorporado o saber administrativo (Lei do Exercício Profissional, $\mathrm{n}^{\circ}$. 7.498/86, Art. 12) envolvendo orientação e acompanhamento do trabalho de enfermagem em grau auxiliar, e participação no planejamento da assistência de enfermagem (BRASIL, 1986).

Porém, dada a operacionalização do estágio, os estudantes não são realmente inseridos no trabalho da equipe de enfermagem, nem discutem as articulações necessárias entre as distintas práticas para que esse cuidar se efetive. Enfim, apenas aprende conceitos/idéias que irão contribuir para a manutenção de práticas hierárquicas e burocratizadas que predominam no contexto hospitalar. 
Isso denota ainda um modo de ensinar pouco articulado à dinâmica cotidiana do trabalho em terapia intensiva, não sendo aproveitado o rico espaço de aprendizado que se constrói quando da inserção efetiva no processo de trabalho em saúde, junto aos demais profissionais.

Casate e Corrêa (2006) enfocam a vivência de estudantes de graduação no estágio hospitalar, é também comentado que durante o estágio, os alunos pouco se inserem na equipe de saúde/enfermagem, porém, essa equipe é seu foco de atenção, eles observam suas ações, relatando atitudes inadequadas que ferem princípios éticos e humanos.

Essa capacidade de pensar do educando pode estar sendo pouco aproveitada pela forma como o estágio em saúde é planejado. O aluno pode até perceber e criticar algumas ações realizadas pelos profissionais, entretanto, não avançam no sentido de refletir ou analisar possibilidades de melhora do processo de trabalho. $O$ ensino de administração em saúde em campo de estágio no contexto deste estudo passa assim a ser pouco valorizado, já que o aluno não consegue vislumbrar qual o seu papel na equipe.

\subsubsection{O emergir da sensibilidade do educando no mundo técnico do CTI}

O educando, mesmo preocupado com a execução da técnica de forma o mais próxima do que foi apresentado em teoria e, às vezes, mostrando-se tão seguro da 
ação que deverá executar, volta também seu olhar para situações que mostram a fragilidade do ser humano.

a gente aprende assim, que quando a gente reclama da vida (...) que "Ah! Tồ com aquela dor!", mas quando a gente vê os pacientes daqui, como eles são, nós não temos dor né? (A.4)

É triste, é também, igual quando a gente foi cuidar daquele paciente sem prognóstico. (A2)

(...) deve ser muito bom você ver um paciente naquele estado sair bem, assim ,é triste, tudo bem assim quando morre. Mas morre em todas as enfermarias, acho que ali deve ser muito bom, na hora que você vê um paciente sair, deve ser muito bom ver ele sair de lá.(A1)

a gente foi aprender assim, aprendi muito, das coisas que eu aprendi no técnico inteiro, foi ali que eu pude fazer as técnicas diferentes, e também mudou muito o jeito da gente pensar (...) a dar mais valor a vida (A10)

Todavia, na maior parte das entrevistas, o sentimento pelo outro se restringe ao sentir pena ou "dó", ou a trazer aquela condição, de estar gravemente doente, a um ente querido, uma pessoa próxima ou para ele mesmo. O fazer humanizado, a empatia, é ainda muito confundida, principalmente em situações nas quais se deparam com a finitude humana.

eu sinto dó do paciente, eu sinto pena, porque você tá afi vendo o paciente sofrer e não pode fazer nada por ele, assim você faz a sua parte, mas você sabe que eu não tenho o poder de salvar a vida da pessoa, mas eu tenho muita pena, eu vejo os 
outros falarem, eu me ponho no lugar ou penso que pode ser um parente meu, mas eu penso diferente (...) se fosse um parente eu não ia gostar de ver sofrendo daquele jeito (...) (A.6)

também mudou meu jeito de pensar, a dar mais valor à vida. Porque ali os pacientes são muito debilitados, totalmente dependentes de nós, você fica pensando que podia ser um parente seu, você quer cuidar melhor, você fica se pondo no lugar dele o tempo todo, imagina você ficar ali, sedado, sem saber onde você tá direito, então você acaba dando mais valor às coisas.(A.10)

(...) me ponho no lugar ou penso que podia ser um parente, mas eu penso diferente (...) se fosse um parente meu eu não iria gostar de ver sofrendo daquele jeito, então eu achei um alivio o Sr. G ter mo (pausa) ter ido à óbito afi, porque ele tava sofrendo demais afi, (...) , e a D. J éa mesma coisa, cada dia que passa ela tá acabando um pouquinho (A. 6)

Porque ali os pacientes são muito debilitados, totalmente dependente de nós, você fica pensando que podia ser um familiar seu, você quer cuidar melhor, você fica se pondo no lugar dele o tempo todo, imagina você fica ali, sedado, sem saber onde você tá direito, então você acaba dando mais valor às coisas. (A.10)

Discutir o significado de sentir dor ou pena torna-se importante. Até que ponto a comiseração permite que se reconheça o outro como pessoa que tem vida própria, que constrói sua existência?

Do mesmo modo, essa comum idéia de que fazer "de conta" que o outro é "parente, conhecido, eu mesmo", apenas mostra a dificuldade em reconhecer e respeitar o outro como ele mesmo, muitas vezes, diferente de mim, mas com direito de ser cuidado. 
Obviamente, o exercício de colocar-se no lugar do outro é fundamental, mas exige que se parta dos valores e concepções do outro, que o tornam singular.

Apesar disso não dá para negar que alguns alunos permitem que venha à tona sua dimensão humana, inclusive, algumas vezes, fora do cotidiano hospitalar, eles se lembram dos doentes que cuidaram, querem saber o que aconteceu com eles, se morreram ou foram para o quarto, e passam a questionar os alunos de outros grupos. Isso revela que a dor do outro de algum modo os tocou.

Há o reconhecimento da condição humana quando o aluno e o supervisor de estágio conseguem perceber o paciente em seu contexto de vida subjetivo e social, o que nem sempre é valorizado no trabalho hospitalar, principalmente, no contexto da terapia intensiva.

Porém, esse sentimento de deixar-se tocar pelo outro precisa ser discutido, refletido, compreendido, a partir de referenciais que possibilitem extrapolar o sensocomum - "da pena", "do cuidar bem, pois podia ser um parente" - para sustentar-se em valores e concepções que tragam o homem como possibilidade de ser.

Testa (1992) em seu artigo sobre sua passagem como paciente em CTI, enfatiza a não consideração da subjetividade e da socialidade do paciente, o que diminui a eficácia da própria intervenção terapêutica.

O ser paciente ou familiar nesse setor traz à tona sentimentos não vividos quando se está em situação de aprendizagem ou atuando como profissional do CTI. O ambiente parece mais frio como o de costume, mais distante e o momento da visita torna-se demasiado triste e solitário, pois é o momento quando normalmente os funcionários ausentam-se do setor. 
Este momento mostra o quanto é difícil, para os profissionais que atuam em setores onde a incerteza no prognóstico de um paciente é uma constante, entrar em contato com a possibilidade de dialogar, compreender e conhecer o sentimento do outro.

Em alguns períodos do estágio, ao término da passagem por esse campo, os alunos falavam claramente sobre seus sentimentos. Porém, isso se dava apenas no último dia, no chamado momento de avaliação, constituindo-se em importante pausa para reflexão. Esse momento poderia ser realizado mais vezes durante o estágio, sendo a interrupção das atividades, quer dizer dos procedimentos, fundamental para a discussão de temas que aproximassem o aluno da pessoa humana a quem ele prestava os cuidados.

Quando de minha experiência como supervisora de estágio, em cursos de auxiliar de enfermagem, tentava realizar momentos de reflexão sobre situações que ocorriam durante o estágio, como a morte de um paciente e a execução de alguns procedimentos. Porém, às vezes, percebia descontentamento entre os próprios alunos e demais supervisores, pois sua expectativa sobre esse estágio era somente um momento de execução de técnicas.

Cabem aqui algumas considerações importantes: essa "pausa" para reflexão pode trazer espaço para ampliar a compreensão sobre a ação de cuidar seja do ponto de vista biológico, psico-social, enfim humano, porém, para tal, como referido anteriormente, valores que ultrapassem o homem a ser cuidado como doença, depositário de técnicas, procedimentos, objeto a ser manipulado, mesmo com a grandiosa intenção de mantê-lo vivo (biologicamente), precisam ser construídos. Caso 
contrário, apenas serão realizadas discussões que não questionam o modo comum de ser/fazer cuidado em CTI.

Daí emerge a formação do professor, profissional que, preocupado com o cumprimento de tantas atividades, responsável pela manutenção da vida daqueles pacientes por meio do trabalho do aluno, pessoas inexperientes, encontra-se em contexto que realmente pode dificultar, à primeira vista, a criação de outros espaços de aprendizagem, mas não se trata somente disso. A problemática reside na dificuldade de desenvolver outro olhar que abarque obviamente a técnica, o biológico, a agilidade, mas também a presença da pessoa humana. E esse "outro olhar" parece estranho no mundo do CTI.

O professor consegue coerência consigo mesmo e com o processo de ensinoaprendizagem quando, ao abordar temas excluídos da grade curricular normalmente aceita como os ligados à subjetividade humana - a dor, a morte, o pesar - se desfaz de "jargões", frases feitas, elaboradas e destituídas de sentido e procura compreender o aluno em sua situação vivida, como algo único, abrindo espaço para um diálogo mais amplo. Essa é talvez uma das atitudes que pode aproximar o ensino profissional em saúde do seu lado humano.

Uma aluna que já trabalhava como auxiliar de enfermagem em outra unidade da instituição hospitalar sentiu-se tocada pelo olhar de um médico e pelo cuidado dispensado por ele a uma paciente. Sua frase dita em um dos encontros finais do estágio, também me tocou muito:

Eu fiquei admirada, porque é uma área que você vê as pessoas tratarem bem. Vê as pessoas terem assim um respeito. Mas na hora que a paciente chegou, eu vi que não 
era um cliente, como eles falam pra gente escrever na anotação. Eu vi que não era só um cliente, eu vi o lado humano dele, ele tava acalmando a paciente, o médico teve a paciência de ficar passando a mão na cabeça da paciente pra acalmar ela, (...) ele teve a sensibilidade de ir passando a mão na cabeça da paciente, tentando acalmar ela porque o que ela precisava era isto, sentir que alguém tava perto (A. 7).

Este momento ocorreu em meio às atividades dos alunos e o que mais me chamou a atenção foi que somente essa aluna remeteu-se a tal situação. Assim, parece já estar explícito o que deva ser visto, valorizado, na terapia intensiva, o que pode ser estendido ao próprio professor.

O momento de óbito de uma paciente também foi muito significativo não só para mim, mas para uma aluna que se sentiu muito incomodada por ter sido convidada, pela supervisora, para participar dos cuidados pós-morte ou somente observá-los junto aos funcionários do setor.

Essa aluna pediu para não participar dessa atividade, atitude aceita pela supervisora, mas não discutida, talvez por ser considerada atitude corriqueira no cenário do CTI. Somente no outro dia, a aluna veio conversar comigo e disse que se lembrara da avó falecida há pouco mais de dois meses, e que não conseguiria ver, naquele momento, uma situação tão similar. A necessidade de conversar a respeito não foi percebida por nenhum dos presentes.

As experiências pessoais fazem parte do aprender humano, devendo ser aproveitadas durante todo o processo ensino-aprendizagem, mas na prática cotidiana dos estágios torna-se esquecida.

Para alguns autores (HAYASHI; GISI, 2000; URIZZI, 2005), o paciente fica reduzido a um objeto dependente de máquinas, tubos e aparelhos que fazem parte do 
cuidar em Terapia Intensiva. Ao não se dar conta onde termina a máquina e começa o paciente, a relação com o sujeito dependente de cuidados torna-se um ato mecânico e o paciente passa a ser visto como uma extensão do aparato tecnológico ali existente.

É importante compreender que tanto a assistência de saúde cotidiana como a formação no contexto do CTI fundamentam-se em uma visão peculiar de homem e mundo. Essa visão, própria do paradigma da modernidade, prioriza o controle da vida humana pelo "modo de ser" técnico, não sendo a vida colhida em suas incertezas (CORRÊA, 2000).

Trincaus (2005) enfoca em sua dissertação de mestrado, na qual é abordado o tema da morte entre pacientes oncológicos em situação de metástase sob o referencial da fenomenologia de Heidegger que, para os profissionais da área da saúde, em especial os que exercem suas atividades em CTI, a morte surge como decorrência da falha do atendimento, associada à rapidez de observação, comunicação e prestação de assistência. A possibilidade de morte é percebida, mas não de forma clara, como uma situação concreta, mas como uma eventualidade.

Apesar das situações emergenciais e do intenso ritmo de trabalho, dada à instabilidade do estado dos pacientes, é possível, em CTI, o profissional de enfermagem exercer um controle rígido do trabalho, utilizando as rotinas. Além disso, a compreensão do outro como ser dotado de uma existência fora do leito do CTI não se faz presente para o profissional que ali atua, considerando que, na visão do profissional, o paciente tende a ficar restrito à presença doente, sendo negado a sua abertura ao passado e ao futuro, o que o restitui como movimento existencial (CORREA, 2000). 
Enquanto o homem a ser cuidado é aprisionado à presença doente, o aluno também o é como agente da técnica, em favor do controle da vida biológica, o que é fundamental, porém, insuficiente ao existir humano. A abertura ao movimento existencial que constitui o homem faz emergir a morte como possibilidade, porém, em $\mathrm{CTI}$, ela quase sempre é tomada apenas como o "elemento" a ser vencido, como algo reconhecido, porém considerado de modo predominantemente técnico e não existencial.

você não sabe se a pessoa vai estar viva, se ela vai te ouvir, não sabe se aquela pessoa vai morrer, você tenta fazer os cuidados pensando sempre em fazer o melhor (A. 7)

é triste, também morre, igual o paciente que a gente cuidou, que eu fiquei sabendo que já morreu, que não tinha mesmo prognóstico (A 2)

Terror porque a gente tem que cuidar de paciente em estado terminal, como aqui. (A3)

A sociedade moderna enfoca a idéia de que a medicina "cura" e que o dever do profissional de saúde é curar; quando isto não acontece surge o sentimento de perda, de incompetência, de insucesso (TRINCAUS, 2005).

Como citado por Urizzi (2005), fundamentada no referencial heideggeriano, convive-se com a morte na terapia intensiva como algo conhecido, que não nos atinge porque está no impessoal. Ou seja, rotineiramente fala-se que alguém morreu, há casos de morte, mas ela não é tomada como questão existencial que toca a cada um de nós quer queiramos ou não. 
porque alguns pacientes que ficam ali, alguns saem, saem dali, outros não, mas afi os médicos investem tudo, o hospital investe tudo o que tem e, às vezes não tem mesmo aquele retorno, o paciente morre mesmo (...) eu vi a questão financeira (...) o quanto foi gasto, investido numa pessoa e depois ela morre não que gastou à toa (...) mas o tanto que foi desperdiçado (...) o CTI é o máximo que você pode tentar pra pessoa viver. (A. 11)

esperava que as pessoas tivessem outra atitude ali, naquela hora. Quando o médico falou já pode desligar os aparelhos, foi uma coisa, assim, um sentimento de impotência mesmo (...) foi um momento tão singular mesmo, assim eu não esperava (A. 11)

A formação do profissional da área da saúde tende a levar o indivíduo a enfocar a morte, no espaço hospitalar, como algo comum, sendo visto por uma perspectiva extremamente técnica. $\mathrm{O}$ aluno tende a se acostumar com a possibilidade da morte do outro, de modo impessoal.

Aproximar-se da possibilidade do morrer como dimensão existencial do próprio educando seria uma importante estratégia para transformar o olhar para o mundo humano e o cuidado em terapia intensiva.

Apesar de algumas iniciativas de escolas de saúde em procurar possibilitar algum preparo aos seus alunos com vistas a lidar com a morte e o morrer, esses esforços têm sido insuficientes e as instituições de saúde mostram-se poucos sensíveis a tais iniciativas.

Como citado anteriormente, a morte é pouco comentada durante o processo de aprendizagem. Em estudo realizado por Boemer (1991), enfocando o tema da morte em um curso de graduação em enfermagem, em disciplina que introduz o aluno ao cuidado 
no cenário hospitalar, foi enfatizada a necessidade de introduzir a abordagem da “educação para a morte" não só nas escolas de graduação em enfermagem, mas, em todos os cursos de saúde.

Para alguns discentes deste estudo, no Centro de Terapia Intensiva, ocorre o primeiro contato com a morte e isto gera grandes expectativas em relação ao estágio. Poder falar sobre a morte durante a passagem pelo campo de estágio e na sala de aula poderia ser primordial no ensino em escolas formadoras de profissionais da área da saúde.

Presenciar a morte é experiência que, quase sempre, faz a pessoa humana refletir sobre sua própria existência, o que é fundamental para profissionais cuidadores. Todavia, de modo geral, sentimentos dos estudantes são considerados como distintos do processo ensino-aprendizagem, denotando muitas vezes, "falta de controle" para a execução correta do trabalho cotidiano. Sem dúvida, isso vem se modificando ao longo do tempo, mas ainda se mantém de modo geral no ensino em enfermagem.

Essa idéia é compartilhada por outros autores (NASCIMENTO et al, 1996), ao afirmarem que em situações de estágio, alunas de graduação em enfermagem sentiam a necessidade de abafar as emoções que emergiam como angústia, tristeza, alegria, às vezes, com um choro contido ou dissimulado, com muito esforço.

Esses sentimentos, na maioria das vezes, são forçosamente contidos, na tentativa de torná-los cabíveis somente ao próprio entendimento. Uma das primeiras lições aprendidas para essas alunas, é a inesquecível frase, "Seja forte, não demonstre suas emoções" e ainda, "Nunca chore na frente dos pacientes" (NASCIMENTO et al, 1996). 
Também vivenciei isto como aluna e ainda questiono porque alguns professores continuam, após tantas discussões a respeito da humanização da assistência, convivendo com esses ideais de fortaleza emocional pelo profissional da saúde.

É interessante notar que quando o educando se refere ao CTI como fonte de estresse, ou quando sinaliza sentimentos ligados à insegurança no cuidar do outro, em algumas vezes ele abaixa o tom de voz como se tentassem esconder as suas fragilidades, de outras pessoas.

Provavelmente, isto seja fruto do próprio despreparo para lidar com esses sentimentos, uma vez que, neste estudo, em alguns momentos do estágio, pude perceber situações como essas, nas quais os sentimentos, mesmo que velados, apareciam diante de mim. Em um momento, quando da morte de uma paciente, a supervisora convidou os alunos a presenciarem os cuidados pós-morte, mas uma das alunas não manifestou interesse, como já comentado anteriormente:

a professora chamou a gente pra fazer 'um pacote', que morreu uma senhora aqui, mas não a que a gente tava cuidando. Mas eu não quis ficar vendo. É que faz só dois meses que a minha avó morreu aqui na geriatria, e a gente ficava muito junto (...) quando eu vi a mulher que morreu também me lembrou bastante ela, porque era velhinha. (A. 3)

Ao tratar o tema morte, o professor pode se sentir inseguro, colocando-se em um contexto impessoal, protegendo-se do sofrimento e da reflexão sobre sua própria finitude, o que o leva a investir mais na técnica e a exigir do aluno um modo de ser mais objetivo. Daí, o surgimento de uma idéia de frieza e insensibilidade que acompanha os profissionais da saúde. 
Lidar com tais situações exigiria outros conhecimentos e atitudes do professor voltadas para o acompanhamento mais próximo do estudante como pessoa. O docente, como dito anteriormente, acompanharia o aluno em todo o desenvolvimento do seu aprendizado, não só de técnicas ou de um conhecimento ligado a patologias e a própria assistência a ser prestada, mas também, em seu crescimento pessoal e social.

De acordo com Delors et al. (2005, p. 157), o trabalho do professor não consiste somente em transmitir informações, mas em mostrá-las aos seus alunos sob a forma de interrogações, de problemas a resolver, situando-as em um contexto e as colocando em perspectiva de modo que ele possa estabelecer a ligação entre a sua solução e outras interrogações mais abrangentes.

Há, pois estreita relação entre o modo de organizar o trabalho em terapia intensiva, fundamentado no modo de ser /cuidar técnico e a formação ancorada em modelos tradicionais de ensino que dão ênfase aos saberes cognitivos e instrumentais, valorizando pouco o próprio aluno e professor em sua integralidade.

Assim, vai mostrando-se nítida a relação entre a construção do cuidado integral em CTI, que não nega a dimensão biológica, mas a amplia conectando-a com outras dimensões do existir humano e a formação que também reconhece os sujeitos e o processo ensino-aprendizagem na perspectiva da integralidade.

Delors et al. (2005, p. 90) firmam os chamados pilares do conhecimento: aprender a conhecer, aprender a viver juntos, aprender a ser e aprender a fazer. Cada um destes deve ser objeto de atenção igual por parte do ensino estruturado, a fim de que a educação apareça como uma experiência global a ser levada pelo indivíduo ao longo de sua vida. 
O aprender a conhecer visa o aumento dos saberes, que permite compreender melhor o ambiente sob os seus diversos aspectos, estimula o sentido crítico e permite compreender o real, mediante a aquisição de autonomia na capacidade de discernir. Este aprender é indissociado do aprender a fazer, embora o segundo esteja estreitamente ligado à questão da formação profissional.

Ainda, o aprender a viver juntos e o aprender a viver com os outros, estão hoje entre os maiores desafios da educação. A educação deve ter como missão, transmitir conhecimentos sobre a diversidade da espécie humana e, ainda, levar as pessoas a tomar conhecimento das semelhanças e da interdependência entre todos os seres humanos.

Além disso, relembra o princípio fundamental da educação segundo os pilares, o aprender a ser. A educação deve contribuir para o desenvolvimento total da pessoa espírito, corpo, sensibilidade, inteligência, responsabilidade social e pessoal. A fim de proporcionar a elaboração de um pensamento autônomo e crítico (DELORS et al., 2005).

Em regra geral, o ensino formal orienta-se essencialmente para o aprender a conhecer e o aprender fazer, enquanto as outras formas de aprender são tidas como prolongamento natural das primeiras.

Em relação à educação profissional, no contexto deste estudo, é destacado o aprender a fazer que estimule o educando a colocar em prática seus conhecimentos, habilidades e atitudes e adaptá-los ao trabalho presente e futuro. Além disso, muitas vezes, investe-se fortemente no aprender a fazer, restrito à dimensão técnica, com pouco empenho na reflexão crítica. 


\subsection{O aprendizado do cuidar do outro em CTI}

Como já foi comentado, o aprendizado do fazer técnico-científico do CTI vai sendo incorporado pelo educando que, inclusive, se sente privilegiado por estudar na única escola do município que faz estágio em terapia intensiva. Uma das alunas inclusive, considera que essa experiência poderá garantir sua inserção futura no mercado de trabalho, uma vez que para ele ter prática em CTI significa ter condições para atuação em qualquer local.

(...) você aprende muito (...) depois que você trabalha em qualquer lugar (...) (A5).

(...) assim, é muito 6om. Assim, essa é a nossa diferença, do nosso curso para os outros. O pessoal que faz o curso aí fora não vê, infelizmente, nossa, não sabe o que ta perdendo, eles não tem noção de tudo isto. (A 1).

Como é destacado por Corrêa (1995), em sua dissertação de mestrado, o campo da terapia intensiva é visto por enfermeiros que ali trabalham, como setor privilegiado no qual permanecem profissionais mais qualificados que se vêem como detentores de um saber técnico mais amplo. Isso acaba por construir o "mito" do profissional do CTI, com suposta competência para atuar em qualquer cenário hospitalar. Mito esse que precisa ser questionado, não negando a competência dos intensivistas, mas redimensionando-o em suas especificidades e limites.

Além disso, o ensino formal não oferece subsídios para que o educando entre no mercado profissional como qualificado para esse ou outro tipo de serviço específico. A 
partir do currículo do curso de Habilitação Profissional de Técnico de Enfermagem pertencente à escola em estudo, os alunos entram em contato com um conteúdo mínimo teórico em disciplinas variadas, além de estágio supervisionado, conforme determina a Resolução CNE/CEB nº 4/99 e, em período determinado em escala (BRASIL, 1999b).

Ou seja, cabe trazer essas pré-concepções sobre a atuação em CTI para reflexão, desmistificando a idéia de um "super-profissional". Ainda cabe considerar, que essas idéias também podem favorecer a exacerbação do saber técnico em detrimento das demais dimensões que qualificariam o cuidar.

As alunas entrevistadas entendem este campo de estágio de forma similar, sentindo-se mais capacitadas por terem a oportunidade de adentrar este ambiente.

Ao adentrar pela primeira vez nesse campo único de atendimento hospitalar, o aluno se sente incomodado com o sofrimento do outro, com a presença constante da morte, enfim com a fragilidade do viver humano, denotando estranhamento com esse cenário. Sentimentos esses compartilhados em minha primeira experiência como enfermeira em um Centro de Terapia Intensiva.

Entretanto, como já comentado, esses sentimentos acabaram sendo reprimidos. Além disso, a auto-afirmação de que é possível trabalhar naquele setor, podendo sendo visto como bom profissional de enfermagem faz com que o aluno considere o mundo do CTI como algo "natural", que exige certa neutralidade, o que é apreendido nos seguintes discursos: "você se acostuma", "faz parte do serviço", "você não pode misturar seu trabalho com sua vida" ou "você não pode se envolver".

São significativas as falas que mostram o movimento vivido pelo aluno do estranhamento à adaptação ao CTI. 
O primeiro dia que a gente entrou eu olhava e pensava, Meu Deus o que é isto, não vou dar conta disso. Depois a gente acostuma, você vê que não é tão difícil, assusta, mas, assim, amei, adorei foi muito proveitoso (A. 1)

$\mathcal{N}$ o começo, primeiro momento parece complicado, parece complicado, parece que a gente pensa que não vai dar conta, mas a gente vai pegando o ritmo, vê que não é nada daquilo, aquele terror. (A. 3)

Eu pensava que ia ficar insegura mesmo, assim, com medo de fazer alguma coisa. Medo de alguém morrer na minha mão, mas aí agora se morrer, faz parte. (A. 3)

No estágio do ano passado o J. abriu a porta (do CTI) e foi um choque, eu pensei, Jossa Meu Deus como é que eu vou dar conta desse paciente. - Como é que eu vou dar banho nele? Eu pensava, - Meu Deus eu nunca vou conseguir cuidar de um paciente assim, e eu vi que eu consigo. (A. 4)

Vou ser sincera, eu tinha medo, eu ficava pensando em como eu ia conseguir fazer as coisas, assim virar um paciente. E você acaba vendo que não é um bicho de sete cabeças, que não é assim, você consegue é só questão de se adaptar. (A. 5)

Assim, o estranhamento e insegurança iniciais parecem acomodar-se, aos poucos, no aprendizado de um fazer rotineiro. "Acostumar-se, pegar ritmo, adaptar-se" podem denotar um enquadramento àquele mundo que pode afastar o aluno do questionamento e da "dimensão humana" do cuidar. A possível perda da capacidade de questionar a dimensão do cuidado pode banalizar aquele cenário, dificultando o despertar da sensibilidade no sentido de colocar-se no lugar do outro para o qual aquele cenário é tão temido como o era, em um primeiro momento, para o profissional. 
Há talvez um interessante movimento: no início do estágio, os sentimentos dos alunos são muito próximos aos dos pacientes e familiares. É claro que a estranheza inicial do profissional tem que se dissipar, em parte, para que ele consiga trabalhar de maneira coerente à terapia intensiva. Porém, o que pode trazer implicações para o cuidar é a simples adaptação, que pode retirar "por completo" a estranheza, no sentido de fazer com que o estudante deixe de indignar-se com o que é invasivo, estranho e agressivo ao homem.

Além disso, a perda da estranheza, da indignação, afasta o estudante do exercício da crítica e da sensibilidade, centrando-se no fazer técnico. Essa busca pela adaptação é também incentivada pelo professor que, de certo modo, também precisa dela, para dar conta de ensinar o cuidado em terapia intensiva.

Esse aprendizado centrado no fazer técnico impede até mesmo o aluno de perceber que o mundo humano é sempre o mundo de relações. Nesse sentido, tem-se como prioritário que o aluno dê conta das tarefas do plantão, relacionando-se apenas com seu colega (dupla) e com a professora, com poucas oportunidades para relacionarse com os demais envolvidos na terapia intensiva. Isso mostra limites consideráveis: Como construir um cuidado integral, sem exercitar a prática do trabalho em equipe?

Dada sua inexperiência técnico-científica, o período curto de estágios e as poucas oportunidades para reflexão, o aluno poderá tender a imitar comportamentos e atitudes de profissionais mais experientes, quando de sua inserção profissional em terapia intensiva, buscando assim, vencer a estranheza e a insegurança e adquirindo capacidade de controle daquele ambiente.

Corrêa (2000), em trabalho de doutorado, no qual busca a compreensão do "treinamento" do enfermeiro recém-admitido em terapia intensiva, comenta que a 
preocupação descontextualizada com o fazer mostra-se significativa quando a intenção é apenas a adaptação. O "treinamento" é realizado por profissionais que estão há mais tempo naquele local de trabalho, sendo o modo como executam suas tarefas, com ênfase na dimensão técnico-biológica, repassado aos mais novos. Cria-se assim uma rotina do setor, um modo de fazer, que pode extinguir possibilidades de um novo fazer do cuidar que considere o homem em sua individualidade e integralidade.

Assim, de modo similar ao "treinamento" do profissional o estágio é uma estratégia que pode moldar comportamentos e atitudes. A lógica ensino-aprendizagem é bastante tradicional, sendo constituída pela devolução de técnicas. O aluno passa a ser avaliado como executor de tarefas, sendo o caderno individual de procedimentos, citado no início, um instrumento de controle valorizado. Assim há poucas perspectivas de se investir em uma prática criativa, sensível e ampliada do cunho técnico.

A perspectiva funcionalista concebe a educação como forma de adaptar o outro ao serviço, valorizando a reprodução do fazer tecnicista em contraposição à valorização do ser humano como agente de transformação.

Durante o treinamento é firmada a separação sujeito-objeto de conhecimento, ou seja, o agir profissional é tido como algo externo às experiências vividas pelo treinando. É muito comum a preocupação com o como treinar para que o outro reproduza a prática, no sentido de fazê-la adequadamente. Assim, o treinamento tem o objetivo de disciplinar e condicionar o treinando a uma prática (CORRÊA, 2000). Essa idéia também se apresenta no estágio do estudante no contexto da terapia intensiva.

De acordo com Corrêa (2000, p.92), "a lógica é adaptá-lo (o profissional) àquele fazer e é tal adaptação que ele também busca para que se mantenha naquele trabalho, que não deixa de ser visto como um modelo". 
É a tônica do mundo moderno: o progresso técnico científico pode "coisificar" o homem, que acaba por se situar no CTI intermediado por instrumentos, regras e

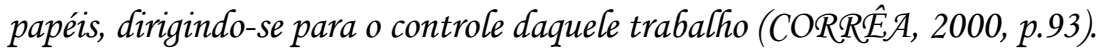

Outra dimensão importante que emerge em campo de estágio é a dificuldade dos alunos realizarem a transição do ensino da sala de aula ao ensino clínico e às atividades prático-assistenciais. O entrosamento entre a instituição de saúde e de ensino com os alunos deve ser focalizado como elemento vital para o aprendizado em campo de estágio, para que os objetivos sejam alcançados (ITO; TAKAHASHI, 2005).

Isso mostra a desarticulação teórico-prática que acaba por fortalecer ainda mais a reprodução do cotidiano, em detrimento da prática reflexiva e criativa. Assim, como já comentado corre-se o risco de reduzir a formação profissional ao treinamento/instrução.

De acordo com Rezende (1989, p.48),

é verdade que o homem também pode ser adestrado, amestrado, treinado, domesticado. Mas isto não é aprendizagem, ou ao menos, não é aprendizagem humana. Ao contrário, quando isto acontece assistimos a um processo de regressão, como fator de desumanização e alienação.

Treinamento/instrução limitam a possibilidade de construir um processo formativo voltado para o educando como pessoa integral, cujas ações, conhecimentos e habilidades têm que ser continuamente refletidos e reconstruídos e não apenas repetidos.

Essa forma predominante de estágio não é exclusiva da escola que foi foco desta pesquisa, é adotada por outras escolas, tanto de nível técnico como de nível superior 
de graduação em enfermagem. Apesar de amplamente difundida no meio acadêmico, essa forma de estágio necessita ser repensada: será que ela pode viabilizar a construção do cuidar integral em terapia intensiva? A passagem apenas por campos de estágio tão densos do ponto de vista tecnológico é mesmo necessária para a formação profissional?

Do ponto de vista até então exposto, cabem reflexões quanto às implicações desta passagem pelo CTI dos educandos do curso técnico em enfermagem: em período tão curto de experiência, com um modelo de estágio reprodutor da prática tecnicista e biologicista, ele poderá ter lacunas na sua formação para assumir o papel de agente de mudanças no cotidiano do trabalho em terapia intensiva, quando de sua inserção profissional.

Obviamente isso não se restringe à prática em CTI, mas ela se mostra importante cenário que permeia a formação profissional, trazendo possíveis implicações para a transformação do cuidar cotidiano em enfermagem. 
6. DA FORMAÇÃO TÉCPICA À EDVCAÇÃO INTTEGRAL 
No ensino profissional tem havido o crescimento do número de vagas e cursos e também da procura pelas mesmas, em alguns casos pela necessidade financeira de adentrar rápido no mercado de trabalho ou pela insuficiência de vagas do ensino superior, ou mesmo pela vontade de realização de um sonho, como fora falado por alguns alunos que sonhavam em ser enfermeiros ou cuidar de doentes, ou que viam a profissão enfermagem como algo bonito e como "dom".

A vivência no meio hospitalar, como dito anteriormente, trouxe-me algumas experiências marcantes. A observação constante de um cuidar mecanicista, principalmente no mundo da terapia intensiva alardeava-me constantemente e, hoje percebo que também em mim existiam alguns sinais desse cuidar mecânico, desse não olhar o ser doente como ser humano com experiências e vivências anteriores.

Ao questionar o educando a respeito da sua passagem pelo Centro de Terapia Intensiva buscava respostas a essas indagações, queria compreender como esse aluno, ainda em processo de formação sentia o doente a quem ele prestava o cuidado e como ele via o seu próprio aprendizado naquele cenário.

Ao ler as entrevistas e relembrar como foi a participação desses alunos em campo de estágio, sobressai a visão do cuidar mecanicista e a valoração da técnica/procedimentos. Percebe-se assim que o bom profissional de enfermagem é aquele que executa todas as técnicas de forma rápida, com boa destreza manual e isenta de erros. A visão do cuidar humano, preconizado pelo meio acadêmico e pela política do Ministério da Saúde que incentiva campanhas para Humanização do Atendimento, é esquecida no momento crucial para formação desses profissionais.

Admirava-me perceber que em meio a tantos alunos no mesmo ambiente, situações nas quais o "con-viver" humano sobressaía eram pouco analisadas. 
O culto à técnica, embora algo muito discutido em aulas teóricas, é visto em campo de estágio como algo natural, pois é a oportunidade do aluno executá-la antes de se tornar profissional da área. Durante o período de avaliação, o tempo de discussão sobre as percepções dos alunos sobre seu aprendizado e experiência de cuidar é relegado em favor do preenchimento do livro de técnicas, instrumento esse que serve para registro e lembrar ao aluno dos procedimentos que não executou.

A abordagem fenomenológica possibilitou-me compreender melhor o meio a que pertenço, trouxe-me algumas concepções esquecidas em um cenário tão competitivo e marcadas por relações de autoridade e disciplina. Enfim, possibilitou-me voltar à reflexão. Hoje consigo valorizar um pouco mais o saber do outro, mesmo que esse outro seja apenas uma criança aprendendo a conhecer o mundo em que vive. Hoje, é assim que me sinto, procuro conhecer o mundo em que habito com os outros.

Compreender o que é o "ser-humano-doente" e o "ser-humano-profissional" é algo ainda incipiente no meio acadêmico nos dias de hoje, e transpondo-a ao estudante quando se depara com a condição humana do doente no CTI valoriza mais o palpável e mensurável do cuidado com o corpo através da técnica e equipamentos.

Ao iniciar esse trabalho julgava o período disposto para sua execução demasiado longo, hoje percebo o quanto ele foi curto e o quanto tenho de me aprofundar no estudo dessa perspectiva metodológica, que ainda me impede de realizar aprofundamentos teóricos.

O tema educação voltado à possibilidade de formação do "ser-humano-com-osoutros", torna-se indiretamente o foco de interesse desta pesquisa fenomenológica. É na vivência de práticas da educação que se exercitam ações de convivência, 
autoridade, confiança e muitos outros modos de viver em sociedade (GARANHANI, 2004).

No decorrer deste trabalho, tive a oportunidade de revisar ações, regras e conceitos, ou seja, repensar o meu viver como enfermeira e como docente a partir da observação das experiências dos educandos, que geraram em alguns momentos desconforto e inquietações.

Realizar o processo de reflexão durante os capítulos construídos, facilita compreender a minha trajetória no desenrolar desta pesquisa.

O encontro com a enfermagem: a prática assistencial e a educativa reflito sobre as condições que me levaram a escolher pela enfermagem hospitalar, e como se deu o meu contato com os estagiários do curso profissionalizante, técnico de enfermagem, e ensino superior.

Hoje percebo o quanto valorizei o pensar lógico e racional, instrumentos de alta tecnologia em detrimento às relações humanas no exercício profissional de enfermeira assistencial e docente.

O ensino profissionalizante busca recuperar alguns dados sobre a gênese do ensino profissional no Brasil e o quanto ele se destacou ao longo dos anos. Divido essa parte em duas outras, primeiro o desenvolvimento do ensino profissional geral e o ensino específico na área da saúde, destacando a enfermagem.

Atualmente a discussão em torno do ensino profissionalizante tem sido alvo de críticas por ser considerado um meio de conter o acesso ao ensino superior, que apresenta grande procura e insuficiente número de vagas em universidades públicas. O desenvolvimento do ensino profissional em enfermagem apresenta particularidades 
políticas e econômicas, condizente com o modelo capitalista e da saúde, curativo e hospitalocêntrico.

Apesar das indicativas de mudanças nas políticas atuais dos campos da saúde e educação, voltadas à implantação do SUS e Diretrizes Curriculares para a integralidade do cuidado e à formação crítico - reflexiva e integral.

A fim de contextualizar ser aprendiz com ser doente no CTI, durante o curso profissionalizante, fiz algumas aproximações sobre $\mathbf{O}$ Centro de Terapia Intensiva e a política de humanização da atenção à saúde no contexto do SUS delimitando algumas de suas características.

$\mathrm{Na}$ Abordagem Metodológica procurei realizar a aproximação ao método fenomenológico embora ainda necessite aprofundar-me nesse referencial teórico, devido às idéias não fazerem parte de uma convivência contínua nos dias atuais, quando a praticidade e a lógica normativa fazem-se prioritárias em quase todas as áreas de atuação do enfermeiro.

Embora a educação não tenha sido considerada tema principal, ou alvo de referência dos pesquisadores fenomenológicos, seus ideais se aproximam da necessidade de mudança no sistema educacional até hoje vigente.

O Acesso ao Educando deu-se de forma gradual e seguindo os preceitos éticos estabelecidos em pesquisa. Procurei estabelecer uma relação de confiança com os colaboradores da pesquisa que se disponibilizaram a participar das entrevistas e aceitaram minha observação de campo.

$\mathrm{Na}$ Descrição e compreensão da experiência vivida pelos educandos, procurei mostrar na íntegra alguns trechos de entrevistas e falas durante a execução do estágio, contextualizando a realidade e articulando o que foi observado, o que foi dito, enfim, 
realizando uma integração compreensiva dos dados que pudessem explicitar as vivências do educando, foco deste estudo.

Nesse sentido pude perceber o educando durante meu encontro com A aproximação dos educandos ao mundo técnico da terapia intensiva, espaço onde ocorreu $\mathbf{O}$ emergir da sensibilidade do educando no mundo técnico do CTI e o Aprendizado do cuidar do outro em CTI.

O fazer tecnicista e a valorização dos procedimentos fizeram-se presentes a todo o momento, o que para mim mostra-se inquietante.

O "cuidar-do-outro" ou o "estar-com-o-outro" no CTI tornou na fala de uma das estudantes, "algo mecanizado", "você faz somente o que está prescrito". Estar com o doente não é entendido como troca/construção de relações humanas, sendo destacado os aparelhos instalados no doente, monitores, respiradores e bombas de infusão, para terapêutica clínica.

Esse cuidar mecânico permeia todo o período de estágio que se foca no aprendizado técnico, descontextualizado da dimensão subjetiva e social, seja do doente grave ou do educando.

Essa perspectiva promove pouco espaço para o exercício da crítica em relação ao cuidado que se desenvolve, bem como não considera a sensibilidade inicial e no decorrer da disciplina do estudante como elemento que possa impulsionar ações compromissadas do profissional com a dignidade humana, no contexto do CTI.

Percebo, ao descrever as falas de algumas estudantes e durante a observação do estágio dentro do cenário do CTI, que a formação profissional não pode ser separada do contexto social, do tempo, dos valores, das condições e dos acontecimentos históricos em que se manifesta. A educação deve ser um processo que caminha de 
acordo com a vida dos homens a quem se destina, suas aspirações, exigências, impasses, tensões, mitos, descobertas e visões de mundo. Assim, o professor deve fortalecer o ensino da diversidade ética e cultural. É preciso, nesse cenário, reconstruir os saberes da escola e da formação do professor, que aprende juntamente com o educando no contexto da prática profissional do técnico de enfermagem.

O modelo de ensino, que utilizei por tanto tempo, como a divisão dos alunos em duplas com pouco contato com a equipe de saúde, a fragmentação do cuidado como forma de "ajudar" o aluno a entender o que estava acontecendo com o doente e também a divisão do tempo para que ele pudesse realizar a maior parte dos procedimentos aprendidos anteriormente na teoria, que julgava ser a melhor forma, hoje não faz tanto sentido pensando na aprendizagem com o outro no CTI.

Ao repensar minhas concepções e atitudes, as revivo e percebo novas estratégias que poderiam ter sido utilizadas. Hoje, percebo que na verdade estava tentando moldar os educandos para reproduzirem um dado modelo de cuidado. Percebo esse processo como adestramento e não mais como educação, pois havia a anulação de todo o processo crítico - criativo.

Heidegger deixou sua contribuição para a educação quando fala sobre a condição humana e a natureza do aprendizado, do pensamento e da compreensão.

Para Heidegger,

"Aprender significa conseguir que tudo o que fazemos seja uma resposta ao que de essencial foi endereçado a nós em qualquer tempo. (...) Ensinar é mais difícil do que aprender, porque o ensinar exige que se deixe aprender."

(Palmer, J., 2006, p.38) 
A educação que motiva predominantemente a aprendizagem escolar, no contexto deste estudo, deriva de conceitos instrumentais que fogem de questões relativas ao sentido da vida e do engajamento do educador e educando no contexto social.

Ao considerar a educação um fenômeno, começamos a reconhecer que se trata de uma experiência profundamente humana. De acordo com Rezende (1989, p. 46), todos os homens se educam e só eles o fazem. Para a fenomenologia, o homem não aprende somente com sua inteligência, mas com sua sensibilidade e imaginação.

Entretanto, a formação do profissional de saúde, no caso o técnico de enfermagem, é predominantemente técnica e isto me leva a repensar a forma como o cuidado do outro está sendo aprendido pelo aluno. A construção do cuidado integral realmente se fará possível?

O que podemos compreender é que a formação do técnico está cada vez mais próxima do treinamento em serviço, abrindo poucos campos de reflexão a cerca do cuidado integral, cuidado este não de um organismo doente, mas de um ser biológico, psicológico e social.

De acordo com Rezende (1989), ao falarmos de aprendizagem humana, queremos aprender de maneira humana a ser homens para existirmos como tais, ou seja, pretendemos aprender a ser críticos, criativos e envolvidos com o processo de aprendizagem e não somente estarmos adaptados a determinados situações, isto é moldados a agir segundo padrões pré-estabelecidos.

Ao invés de instruir o educando com uma "falsa cultura", com saberes prédefinidos e orientados para o aprendizado de determinadas habilidades, é preciso sem isolá-los da sociedade em que vivem, incentivá-los a pensar, questionar, criar e superar o homem em sua subjetividade. Sem dúvida, os animais podem ser treinados, mas, só 
o homem é capaz de ensinar e aprender, atividades essencialmente humanas e profundamente significativas para sua existência (COÊLHO, 1999).

Ao utilizarmos o cenário do CTI como campo de aprendizado deveríamos confrontar o modelo altamente biologicista e tecnicista ao modelo integral do cuidado, articulando-os ao cuidado em CTI no contexto social e subjetivo do homem gravemente doente.

Cabe refletir sobre formação ampliada para além do eixo técnico, o que implica em mudanças na forma de ensinar, na forma de ser aluno e professor e de fazer o trabalho em terapia intensiva.

Não se trata simplesmente de decidir se devemos ou não inserir atividades em terapia intensiva, mas refletir sobre as finalidades dessa inserção no ensino técnico em enfermagem, não perdendo de vista a possibilidade de considerar a prática de ensino como potencializadora de transformações no cuidar. Para tal precisam ser redimensionados os modelos curriculares, as metodologias de ensino, bem como a formação docente. 
AMÂNCIO FILHO, A. Dilemas e desafios da formação profissional em saúde. Interface - Comunicação, Saúde e Educação, v. 8, n. 15, p. 375-80, maio/ago. 2004.

BARATO, J. N. Escritos sobre tecnologia educacional \& Educação profissional. São Paulo: Ed. SENAC, 2002.

BARTMANN, M. Evolução histórica dos cursos de auxiliar e técnico de enfermagem. Boletim técnico do SENAC. Disponível em: http://157.86.204.63/cold/profae/biblioteca2/arqs/Mercilda.htm 2004. Acesso em: 10 fev. 2004.

BICUDO, M. A. V.; ESPÓSITO, V. H. C. Pesquisa qualitativa em educação: um enfoque fenomenológico. Piracicaba: Ed. UNIMEP, 1994.

BOEMER, M. R. A temática da morte sob a perspectiva da pesquisa fenomenológica do fenômeno situado. Cad. Soc. Est. Pesq. Qualit., v. 2, p. 65 - 84, 1991.

BOEMER, M. R.; CORRÊA, A. K. Repensando a relação do enfermeiro com o doente: o resgate da singularidade humana. In: BRANCO, R. F. G. R. A relação com o paciente: teoria, ensino e prática. Rio de Janeiro: Guanabara-Koogan, 2003. Cap.38, p. 263-69.

BRASIL. Conselho Federal de Enfermagem. Lei $n^{\circ} 7498$, de 25.06.1986. Dispõe sobre a Regulamentação do Exercício Profissional da Enfermagem e dá outras providências. Disponível em: http://www.lei.adv.br/7498-86.htm. Acesso em: 04 set. 2006

Resolução do Conselho Federal de Enfermagem, COFEN no 8967 de 28.12.1994. Altera a redação do parágrafo único do art. 23 da Lei 7498 , de 25.06.1986, que dispõe sobre a regulamentação do Exercício da Enfermagem e dá outras providências. Disponível em: http://www.portalcofen.gov.br/2007. Acesso em: 03 mar. 2007

. Conselho Nacional da Educação. Lei $\mathrm{n}^{\circ}$ 9394, de 20.12.1996. Estabelece as Diretrizes e Bases da Educação Nacional. Brasília, 1996a Disponível em: http://www.portalmec.gov.br. Acesso em: 08 set. 2005

. Ministério da Saúde. Conselho Nacional de Saúde. Resolução 196/96. Dispõe sobre a pesquisa envolvendo seres humanos. Brasília, 1996b.

. Conselho Nacional da Educação. Decreto $\mathrm{n}^{0} 2208$, de 17.04.1997. Regulamenta o parágrafo 2 do art. 36 e os arts. 39 a 42 da Lei $n^{\circ} 9394$, de 20.12.1996, que estabelece as Diretrizes e Bases da Educação Nacional. Brasília, 1997. Disponivel em: http://pedagogiaemfoco.pro.br/d2208 97.htm. Acesso em: 02 set. 2007 
. Conselho Nacional da Educação. Resolução CNE/CEB $n^{\circ} 4$ de 8 de dezembro de 1999. Institui as Diretrizes Curriculares para a Educação Profissional de Nível Técnico. Diário Oficial da União, Brasília, 22 de dezembro de 1999, 1999a.

. Conselho Nacional da Educação. Parecer CNE/CEB nº 16 de 26 de novembro de 1999. Diretrizes Curriculares para a Educação Profissional de Nível Técnico. Diário Oficial da União, Brasília, 22 de dezembro de 1999, 1999b.

Ministério da Saúde. PROFAE, v. 5. Brasília, jan. 2000a.

. Ministério da Saúde. PROFAE, v. 6. Brasília, jan. 2000b.

. Ministério da Saúde. FORMAÇÃO, PROFAE, v.1, n.1, Brasília, jan. 2001a

, Ministério da Saúde. Programa Nacional de Humanização da Assistência Hospitalar. Brasília, 60p, 2001b

. Resolução do Conselho Federal de Enfermagem, COFEN n² 276/2003. Regula a concessão de Inscrição Provisória ao Auxiliar de Enfermagem. In: COREN: Educação em Enfermagem, São Paulo, n. 46, p. 16-17, ago. 2003

. Conselho Nacional de Educação. Decreto $n^{\circ}$ 5154, de 23.07.2004. Regulamenta o parágrafo 2 do art. 36 e os arts. 39 a 41 da Lei $n^{\circ} 9394$, de 20.12.1996, que estabelece as Diretrizes e Bases da Educação Nacional. Brasília, 2004. Disponível em: http://www.planalto.gov.br/ccivil. Acesso em: 02 set. 2007

Ministério da Saúde. RET-SUS. Disponível em: http:// www.retsus.epsjv.fiocruz.br/. Brasília, março 2006. Acesso em: 04 set, 2006

Ministério da Saúde. RET-SUS. Disponível em: http:// www.retsus.epsjv.fiocruz.brl. Brasília, março 2007. Acesso em: 04 set, 2006

CAPELLA, B. B.; FARIA, E. M.; GELBCKE, F. L.; SPRICIGO, J. S. Profissionalização da enfermagem: uma necessidade social. Rev. Bras. Enferm., Brasília, v. 41, n. 2, p. 161-68, abr./jun.1988.

CARVALHO, M. D. B. et al. Expectativas dos alunos de enfermagem frente ao primeiro estágio em hospital. Rev. Esc. Enferm.USP, São Paulo, v. 33, n. 2, p. 2006, 1999.

CASATE, J. C.; CORRÊA, A. K. Vivências de alunos de enfermagem em estágio hospitalar: subsídios para refletir sobre a humanização em saúde. Rev.. Esc. Enferm.USP, São Paulo, v. 40, n. 3, p. 321-8, 2006. 
CASTRO, D. S. P. et al. (Orgs.). Existência e saúde. São Bernardo do Campo: Universidade Metodista de São Paulo, SOBRAPHE, 2002. 256 p.

COÊLHO, I. M. Fenomenologia e educação. In: BICUDO, M. A. V. CAPELLETTI, I. F. Fenomenologia: uma visão abrangente da educação. Olho Mágico, São Paulo, 1999.

COREN/SP. Documentos básicos de enfermagem. São Paulo, 2001.

CORREAA, A. K. Sendo enfermeira no centro de terapia intensiva. Ribeirão Preto, 1995. 119 f. Dissertação (Mestrado) - Escola de Enfermagem de Ribeirão Preto, Universidade de São Paulo, Ribeirão Preto, 1995.

Fenomenologia: uma alternativa para pesquisa em enfermagem. Rev. Latino-am. Enferm., Ribeirão Preto, v. 5, n. 1, p. 83-8, jan. 1997.

O paciente em centro de terapia intensiva: reflexão bioética. $\underline{\text { Rev }}$. Escola de Enferm. USP, São Paulo, v. 32, n. 4, p. 297-301, dez. 1998.

- Do treinamento do enfermeiro à possibilidade da educação em terapia intensiva. Em busca da existência humana. Ribeirão Preto, 2000. 212 f. Tese (Doutorado) - Escola de Enfermagem de Ribeirão Preto, Universidade de São Paulo, Ribeirão Preto, 2000.

DARTIGUES, A. O que é a fenomenologia? Trad. Maria José J. G. de Almeida. $8^{a}$ ed. São Paulo: Ed. Centauro, 2003.

DELORS, J. et al. Educação: um tesouro a descobrir. Relatório para a UNESCO da Comissão Internacional sobre Educação para o Século XXI. 10 ${ }^{a}$ ed. São Paulo: Cortez; Brasília, DF: MEC: UNESCO, 2005.

DUPAS, G.; PAVARINI, S. C. I. O processo de cuidar em enfermagem: com a palavra os enfermeiros de uma instituição hospitalar. Acta Paul. Enferm., São Paulo, v. 12, n. 2, p. 73-84, 1999.

EBISUI, C. T. N. A identidade profissional do enfermeiro professor do ensino técnico de enfermagem. Ribeirão Preto, 2004. Dissertação (Mestrado) - Escola de Enfermagem de Ribeirão Preto, Universidade de São Paulo, Ribeirão Preto, 2004.

FRIGOTTO, G. Trabalho, conhecimento, consciência e a educação do trabalhador: impasses teóricos e práticos. In: GOMEZ, C. M. et al. Trabalho e conhecimento: Dilemas na educação do trabalhador. 4ª ed. São Paulo: Cortez, 2002.

GARANHANI, M. L. Habitando o mundo da educação em um currículo integrado de Enfermagem: um olhar à luz de Heidegger. Ribeirão Preto, 2004. Tese (Doutorado) Escola de Enfermagem de Ribeirão Preto, Universidade de São Paulo, Ribeirão Preto, 2004. 
GÓES, H. L. de F. Contribuição dos exames de suplência profissionalizante na formação dos atendentes de enfermagem em Maringá-PR. Ribeirão Preto, 1999. Dissertação (Mestrado) - Escola de Enfermagem de Ribeirão Preto, Universidade de São Paulo, Ribeirão Preto, 1999.

GÓMEZ, C. M. et al. Trabalho e conhecimento: dilemas na educação do trabalhador. . 4ª ed. São Paulo: Cortez Editora, 2002.

GRYSCHEK, A. L. F. P. L.; ALMEIDA, A. H.; ANTUNES, M. N.; MIYASHIRO, S. Y. Projeto Larga Escala: uma proposta pedagógica atual. Rev. Esc. Enferm. USP, São Paulo, v. 34, n. 2, p. 196-201, jun. 2000.

HAYASHI, A. A. M.; GISI, M. L. O cuidado de enfermagem no CTI: da ação-reflexão à conscientização. Texto Contexto Enferm., Florianópolis, v. 9, n. 2, pt. 2, p. 824-37, maio/ago. 2000

ITO, E. E.; TAKAHASHI, R. T. Publicações sobre Ensino em Enfermagem na Revista da Escola de Enfermagem da USP. Rev Esc. Enferm. USP, São Paulo, v. 39, n. 4, p. 409-16, dez. 2005.

KOBAYASHI, R. M. Caracterização da disciplina: Noções de Administração de Enfermagem. 2002 Dissertação (Mestrado) - Escola de Enfermagem, Universidade de São Paulo, São Paulo, 2002.

LIMA, M. A. D da S. O trabalho de enfermagem na produção de cuidados de saúde no modelo clínico. 1998. 216 f. Tese (Doutorado) - Escola de enfermagem de Ribeirão Preto, Universidade de São Paulo, Ribeirão Preto, 1998.

LOBO NETO, F. J. da S. et al. Educação - Formação Pedagógica em educação profissional na área da saúde: enfermagem, módulo 1. Brasília: Ministério da Saúde, 2000.

LUDKE, M.; ANDRE, M. E. D. A. Pesquisa em educação: abordagens qualitativas. São Paulo: EPU, 1986.

MANFREDI, S. M. Educação profissional no Brasil. São Paulo: Cortez Editora, 2002.

MARTINS, J.; BICUDO, M. A. V. A pesquisa qualitativa em psicologia: fundamentos e recursos básicos. $5^{\text {a }}$ ed. São Paulo: Ed. Centauro, 2005.

MARTINS, J.; BOEMER, M. R.; FERRAZ, C. A. A fenomenologia como alternativa metodológica para pesquisa: algumas considerações. Rev. Esc. Enferm.USP, São Paulo, v. 24, n. 1, p. 139-47, abr. 1990. 
MARTINS, J. Um enfoque fenomenológico do currículo: educação como poíesis. São Paulo: Cortez Editora, 1992.

MENDES, S. R. Cursos técnicos pós-médios: análise das possíveis relações com o fenômeno de concentração da demanda pelo ensino superior. Trabalho, educação e saúde, v. 1, n. 2, p. 267-87, 2003.

NASCIMENTO, E. S. et al. O cotidiano dos alunos de enfermagem no aprendizado prático da profissão. Enferm. Rev., Belo Horizonte, v. 2, n. 5, p. 37-52, dez. 1996.

OGUISSO, T.; SCHMIDT, M. J. O exercício da enfermagem: uma abordagem éticolegal. São Paulo: Ed. LTR, 1999.

OLIVEIRA, L. S. S.; LAMPE, G. N.; MARTINS, C. L.; MIYASHIRO, S. Y. Profissionalização de atendentes de enfermagem no estado de São Paulo: um estudo sobre a oferta e demanda de formação. Rev Latino-am. Enferm., Ribeirão Preto, v. 10, n. 5, p. 637-43, set./out. 2002.

PALMER, J. 50 Grandes educadores modernos: de Piaget a Paulo Freire. São Paulo: Ed. Contexto, 2006. p. 38-43.

PEIXOTO, M. R. B. A prioridade, o isolamento e as emoções: estudo etnográfico do processo de socialização em um Centro de Terapia Intensiva. 1996. 248 f. Tese (Doutorado) - Escola de Enfermagem, Universidade de São Paulo, São Paulo, 1996.

PINHEIRO, C. T. dos S. O paciente e seu atendimento em terapia intensiva. In: BARRETO, S. S. M.; VIEIRA, S. R. R.; PINHEIRO, C. T. dos S. et al. Rotinas em terapia intensiva. $3^{\mathrm{a}}$ ed. São Paulo: Artmed, 2001.

PIRES, D.; GELBECKE, F. L.; MATOS, E. Organização do trabalho em enfermagem: implicações no fazer e viver dos trabalhadores do nível médio. Trabalho, educação e saúde, v. 2, n. 2, p. 311-25, 2004.

REVISTA do HCFMRP/USP, Ribeirão Preto, Edição Especial, p. 58, maio 2005.

REZENDE, A. M de. Concepção fenomenológica da educação. São Paulo: Cortez, 1989.

ROCHA, V. K. et al. Pesquisando a existência de resistência por parte da equipe de enfermagem do CTI em assistir pacientes conscientes. Rev. Gaúch. Enferm., v. 17, n. 2, p. 132-9, jul. 1996.

SANTOS, L. H.; CASSIANI, S. H. B. Vivendo em constante conflito: o significado da prática docente no ensino médio de enfermagem. Rev. Latino-am. Enferm., Ribeirão Preto, v. 8, n. 5, p. 58-64, out. 2000. 
SANTOS, L. H. P. Estratégias de ensino-aprendizagem na educação profissional em enfermagem. 2005.Tese (Doutorado) - Escola de Enfermagem de Ribeirão Preto, Universidade de São Paulo, Ribeirão Preto, 2005.

SILVA, S. C. da. Parada cardiorrespiratória na Unidade de Terapia Intensiva: análise das ocorrências iatrogênicas durante o atendimento. São Paulo, 1998. Dissertação (Mestrado) - Escola de Enfermagem, Universidade de São Paulo, São Paulo, 1998.

SIMÕES, S. M. F.; SOUZA, I. E. O. Um caminhar na aproximação da entrevista fenomenológica. Rev. Latino-am. Enferm., Ribeirão Preto, v. 5, n. 3, p. 13-17, julho 1997.

TESTA, M. Visão desde o leito do paciente. Rev. Saúde Mental Coletiva, v. 1, n. 1, p. 47-54, 1992.

TRINCAUS, M. R. A morte em seu mostrar-se ao paciente oncológico em situação de metástase. 2005. Dissertação (Mestrado) - Escola de Enfermagem de Ribeirão Preto, Universidade de São Paulo, Ribeirão Preto, 2005.

URIZZI, F. Vivências de familiares de pacientes internados em terapia intensiva: o outro lado da internação. 2005. Dissertação (Mestrado) - Escola de Enfermagem de Ribeirão Preto, Universidade de São Paulo, Ribeirão Preto, 2005.

VILA, V. da S. C. O significado cultural do cuidado humanizado em Unidade de Terapia Intensiva: muito falado e pouco vivido. 2001. Dissertação (Mestrado) Escola de Enfermagem de Ribeirão Preto, Universidade de São Paulo, Ribeirão Preto, 2001.

ZEM-MASCARENHAS, S. H.; BERETTA, M. I. R. Participando da construção de um projeto pedagógico da enfermagem. Rev. Esc. Enferm. USP, São Paulo, v. 39, n. 4, p. 437-42, dez. 2005. 


\section{ANEXO A - CURRÍCULO DO CURSO DE HABILITAÇÃO PROFISSIONAL EM TÉCNICO DE ENFERMAGEM DO CENTRO INTERESCOLAR DO HCFMRP - USP}

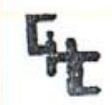

CENTRO INTERESCOLAR - HCRP- FMRP - USP

RIBEIRAO PRETO - SP - o-mail: cinterescolar@iterna.com.br

$$
\text { C URR I C U L O }
$$

CUR S O : Habilitação Profissional de Técnico em Enfermagem

LDB No 9394/96, Decreto 515404, Resołuçăo CNE/CEB 4/99, Parecer CNE/CEB No $16 / 99$ e Indica̧ăo CEE N 8/2000 A conclusảo do Módulo I dá direito ao aluno receber certificado de Auxiliar de Enfermagem

Teórico Prálico: 1223 horas

Estśgio Supervisionado.: 819 horas MÓDULO I

\begin{tabular}{|c|c|c|c|c|}
\hline DISCIPLINA & CONTÉUDO ESPECIFICO & $\begin{array}{l}\text { TEORICO } \\
\text { PRATICO }\end{array}$ & $\begin{array}{l}\text { ESTAGNO } \\
\text { SUPERYR- } \\
\text { SHONADO }\end{array}$ & Total \\
\hline Geatžo em Saúde & $\begin{array}{l}\text { Etica Profissional } \\
\text { História da Enfermagem } \\
\text { Construindo a Relação de Ajuda } \\
\text { Código de Deontologia }\end{array}$ & 30 & - & 30 \\
\hline Fundamentos em Enfermagem & $\begin{array}{l}\text { Anatomia e Fisiologia } \\
\text { Microbiologia e Parasitologia } \\
\text { Introduçăo à Enfermagem }\end{array}$ & $\begin{array}{c}60 \\
30 \\
130 \\
\end{array}$ & $\overline{-}$ & $\begin{array}{c}60 \\
30 \\
195 \\
\end{array}$ \\
\hline Enfermagem Médica & $\begin{array}{l}\text { Enfermagem de Clínica Médica } \\
\text { Enfermagem de Moléstias Transmissiveis } \\
\text { Nutriçăo e Dietética }\end{array}$ & $\begin{array}{l}100 \\
30 \\
30 \\
\end{array}$ & $\begin{array}{r}55 \\
35 \\
- \\
\end{array}$ & $\begin{array}{l}155 \\
65 \\
30 \\
\end{array}$ \\
\hline Enformsgem Cirúrgica & $\begin{array}{l}\text { Enfermagem de Clinica Cirúrgica } \\
\text { Enfermagem de Centro Cirúrgico } \\
\text { Enfermagem de Pronto Socorro }\end{array}$ & $\begin{array}{c}105 \\
40 \\
30 \\
\end{array}$ & $\begin{array}{l}55 \\
20 \\
20\end{array}$ & $\begin{array}{c}160 \\
60 \\
50 \\
\end{array}$ \\
\hline Enfermagem Materno Infantil & $\begin{array}{l}\text { Enfermagom Obstétrica e Ginecológica } \\
\text { Enfermagem Pediátrica }\end{array}$ & $\begin{array}{l}95 \\
80\end{array}$ & $\begin{array}{l}60 \\
70\end{array}$ & $\begin{array}{l}155 \\
150\end{array}$ \\
\hline Eniermagem em Saúde Coletiva & $\begin{array}{l}\text { Programas de Saúde } \\
\text { Imunizaçăo } \\
\text { Saúde da Familia }\end{array}$ & 55 & 35 & 90 \\
\hline & SUB TOTAL (MODULO I) & 815 & .415 & 1230 \\
\hline
\end{tabular}

\begin{tabular}{|c|c|c|c|c|}
\hline \multirow[b]{2}{*}{ DISCIPUNA } & \multicolumn{4}{|c|}{ (1) } \\
\hline & CONTÉUDO ESPECIFICO & $\begin{array}{l}\text { TEÓRICO } \\
\text { PRÁTICO }\end{array}$ & $\begin{array}{l}\text { ESTAGIO } \\
\text { SUPERVI- } \\
\text { SIOALADO }\end{array}$ & TOTAL \\
\hline 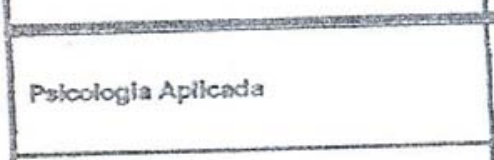 & $\begin{array}{l}\text { Estudo do Comportamento } \\
\text { Psicologia da Forma } \\
\text { Personalidade } \\
\text { Psicologia do Desenvolvimento }\end{array}$ & a & - & 32 \\
\hline Higiene e Profilaxia & $\begin{array}{l}\text { Qualidade da Agua } \\
\text { Lixo, Saúde a Meio Ambiente } \\
\text { Controle das Zoonoses }\end{array}$ & 32 & - & 32 \\
\hline Sséde Ocupaclonal & Higiene e Segurança do Trabalho & 32 & - & 32 \\
\hline $\begin{array}{l}\text { Entermagem Saúde Mental e } \\
\text { Ceriatria }\end{array}$ & $\begin{array}{l}\text { Enfermagem Neurologica } \\
\text { Enfermagem Psiquiatrica e } \\
\text { Gerontogeriatria }\end{array}$ & $\begin{array}{l}40 \\
56 \\
\end{array}$ & 38 & $\begin{array}{l}76 \\
92 \\
\end{array}$ \\
\hline $\begin{array}{l}\text { Enlermagem Intensivista } \circ \text { em } \\
\text { Urganclas }\end{array}$ & $\begin{array}{l}\text { Centro de Terapia Intensiva } \\
\text { Sala de Urgencia }\end{array}$ & $\begin{array}{l}40 \\
40 \\
\end{array}$ & $\begin{array}{l}38 \\
38 \\
\end{array}$ & $\begin{array}{l}76 \\
76 \\
\end{array}$ \\
\hline Farmacologla para Enfermagern & $\begin{array}{l}\text { Grupos e açסes dos medicamentos, Nomes } \\
\text { Genéricos, Similares e Comerciais }\end{array}$ & 40 & 20 & 60 \\
\hline Administraçäo em Enfermagem & $\begin{array}{l}\text { Planejamento em Equipe das AçDes de } \\
\text { Enfermagern }\end{array}$ & 60 & 40 & 100 \\
\hline Informsitica & $\begin{array}{l}\text { Computador e seus Componentes } \\
\text { Rodes de Computadores } \\
\text { Noçoes sobre Windows }\end{array}$ & 36 & $\cdots^{-}$ & 36 \\
\hline & SUB TOTAL (MODULO Ii) & 1. 408 & 204 & 812 \\
\hline
\end{tabular}

Pela Homologaç̌o
HOMOLOGO 


\section{ANEXO B - PERFIL DE COMPETÊNCIAS PARA O CURSO DE HABILITAÇAO PROFISSIONAL EM TÉCNICO DE ENFERMAGEM DO HCFMRP-USP}

1. Prestar assistência de enfermagem em programas de proteçăo, de recuperação e de reabilitação da saúde;

2. Respeitar e considerar os clientes atendidos, e os que procuram os serviços de saúde;

3. Observar as necessidades do paciente sob sua responsabilidade, levando em consideraçăo as diferentes fases do ciclo vital e a extensão dos agravos apresentados pelo mesmo;

4. Assistir pacientes hospitalizados ou em domicilio, levando em consideração variáveis tais como: idade, sexo, complexidade do estado de saúde;

5. Identificar os determinantes e condicionantes do processo saúde/doença;

6. Identificar a estrutura e organização do sistema de saúde;

7. Identificar funçð̄es e responsabilidades dos membros da equipe de trabalho;

8. Planejar e organizar o trabalho na perspectiva do atendimento integral e de qualidade;

9. Realizar trabalho em equipe, correlacionando conhecimentos de várias disciplinas ou ciências, tendo em vista o caráter interdisciplinar da área;

10. Aplicar normas de Biossegurança;

11. Aplicar principios e normas de higiene e saúde pessoal e ambiental:

12. Interpretar e aplicar legislaçăo referente aos direitos do consumidor/usuário;

13. Identificar e aplicar principios e normas de conservaçăo de recursos năo renováveis e de preservação do meio ambiente;

14. Aplicar principios ergonômicos na realização do trabalho;

15. Avaliar riscos de iatrogenias, ao executar procedimentos técnicos;

16. Interpretar e aplicar nomas de exercicio profissional e princípios éticos que regem a conduta do profissional de saúde;

17. Identificar e avaliar rotinas, protocolos de trabalho, instalaçōes e equipamentos:

18. Operar equipamentos próprios do campo de atuação, zelando pela sua manutençăo;

19. Registrar ocorrências e serviços prestados de acordo com exigências do campo de atuação;

20. Informar o cliente/paciente, o sistema de saúde e outros profissionais sobre os serviços prestados;

21. Orientar o cliente/paciente a assumirem, com autonomia, a própria saúde;

22. Coletar e organizar dados relativos ao campo de atuação;

23. Utilizar recursos e ferramentas de informática especificos da área;

24. Realizar primeiros socorros em situação de emergência. 
ANEXO C - ESCALA DE ESTÁGIO - ANO 2006

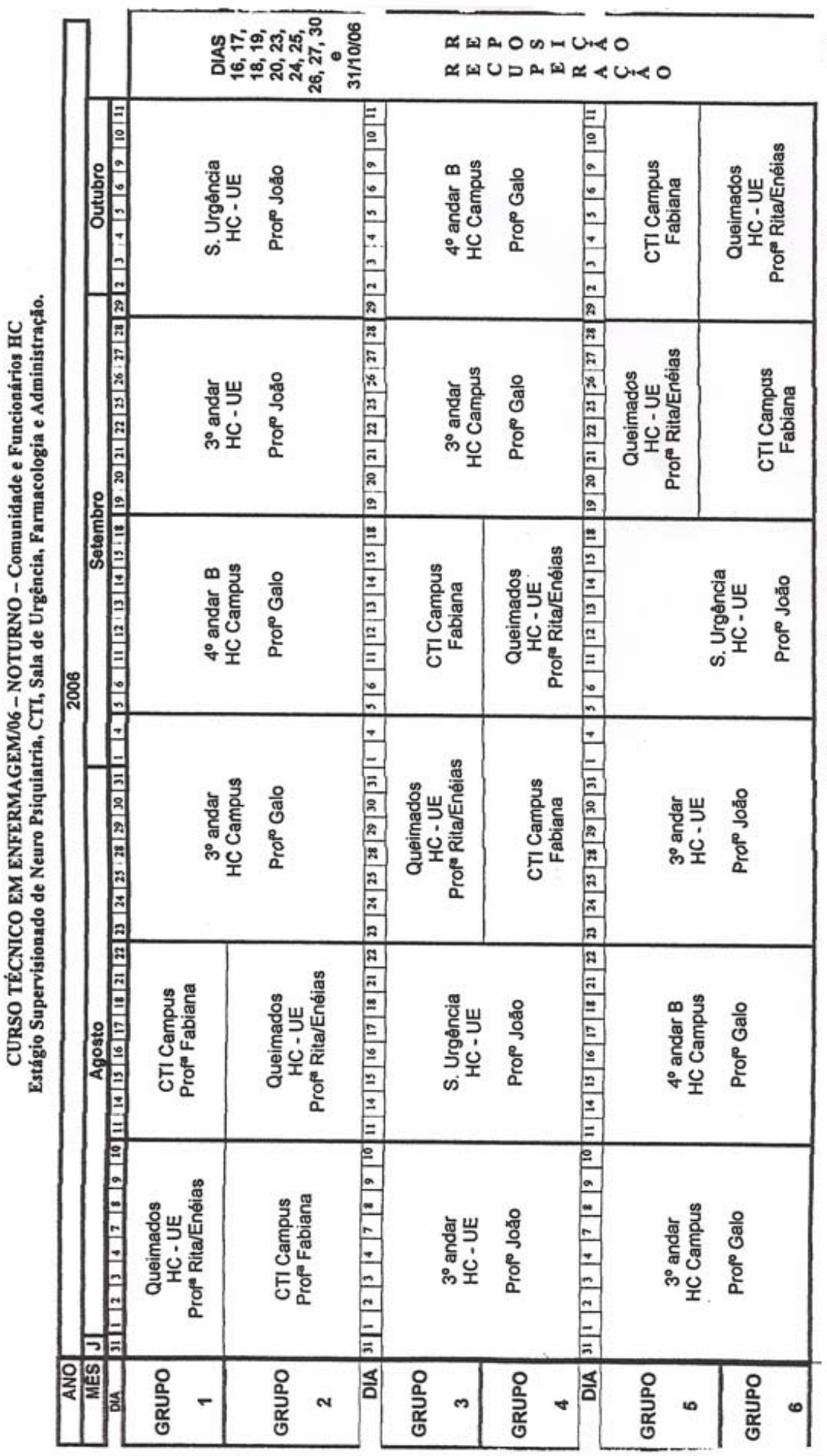




\section{ANEXO D - APROVAÇÃO DO COMITÊ DE ÉTICA EM PESQUISA DO HCFMRP-USP}

HOSPITAL DAS CLINICAS DA FACULDADE DE MEDICINA
DE RIBEIRÃO PRETO DA UNIVERSIDADE DE SÄO PAULO
Comitê de Ética em Pesquisa

Oficio $n^{\circ} 1389 / 2006$

CEP/SPC

Prezada Senhora:

O trabalho intitulado "VIVÊNCLAS DO EDUCANDO DE ENFERMAGEM (EDUCAÇÃO PROFISSIONAL) NO CUIDADO AO DOENTE CRÍTICO)", foi analisado pelo Comitê de Ética em Pesquisa, em sua $225^{a}$ Reunião Ordinária realizada em 22/05/2006, e enquadrado na categoria: APROVADO, bem como o Termo de Consentimento Livre e Esclarecido, de acordo com o Processo HCRP n $3675 / 2006$.

Aproveito a oportunidade para apresentar a Vossa Senhoria protestos de estima e consideração.

PROF. DR. SÉRGIO PEREIRA DA CUNHA Coordenador do Comitê de Ética em Pesquisa do HCRP e da FMRP-USP

Ilustrissima Senhora

RENATA SILVEIRA APPOLINÁRIO PROF $^{a}$ DR $^{\text {a }}$ ADRIANA KATIA CORRÊA (Orientadora)

Escola de Enfermagem de Ribeirão Preto-USP

Depto. de Enfermagem Geral e Especializada

Em mãos 


\section{APENDICE A - TERMO DE CONSENTIMENTO LIVRE E ESCLARECIDO}

Estou realizando a pesquisa intitulada "Vivências do educando de enfermagem (educação profissional) no cuidado ao doente crítico", a ser realizada com alunos do ensino profissional de enfermagem do Centro Interescolar do HCFMRP/USP, nível técnico, durante e após a sua passagem pelo Centro de Terapia Intensiva da Unidade Campus da referida instituição, por meio de observação não participante (ou seja, não terei a função de acompanhá-lo como docente, não interferindo nas suas atividades de estágio, apenas observando-as) e entrevista aberta, na qual o participante responderá à questão "Como é para você cuidar de um doente grave nesse momento de sua formação?" Suas falas serão transcritas para posterior análise. Se for autorizado antecipadamente poderá ser gravada para melhor transcrição posterior. Esta pesquisa visa compreender como tem sido, para o aluno de ensino profissional da área de enfermagem, o aprendizado relacionado ao cuidado de doentes graves de terapia intensiva, para contribuir com sua formação e com a prática de cuidar em CTI.

Esclareço que a sua desistência em qualquer parte do processo de pesquisa é livre e que não trará danos para sua atividade profissional e escolar, bem como a sua participação neste estudo em nada influenciará na sua avaliação. Será assegurado o seu anonimato durante a pesquisa, protegendo assim a sua identidade.

Os dados obtidos serão utilizados em minha dissertação de mestrado a ser apresentada à Escola de Enfermagem de Ribeirão Preto da Universidade de São Paulo e em artigo científico publicado em revista da área.

Disponho-me a responder possíveis dúvidas sobre a atividade a ser realizada mesmo após a assinatura do termo de consentimento livre e esclarecido, tendo o entrevistado meus dados abaixo citados como forma de contato.

Renata Silveira Appolinário

Enfermeira responsável pela pesquisa

Coren/SP: 88849

Rua Augusto Bortolotti, n 440 ap.03

Lagoinha - Ribeirão Preto

(16) 396562 43/ (16) 92093203
Profa. Dra. Adriana Katia Corrêa

Orientadora da pesquisa

Depto. Enfermagem Geral e

Especializada

Escola de Enfermagem de Ribeirão

Preto

Universidade de São Paulo

(16) 36023436.

Entrevistado

Nome:

Idade: 